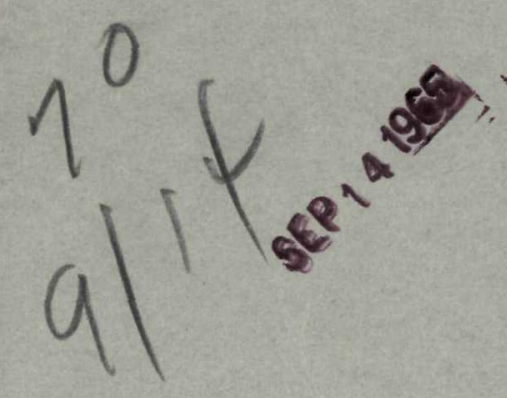

\author{
ORNL-3829 \\ UC-23 - Isotopes-Industrial Technology \\ TID -4500 (43rd ed.)
}

REVIEW OF ISOTOPES TARGET PROGRAM OCTOBER 1963-DECEMBER 1964

E. H. Kobisk

OAK RIDGE NATIONAL LABORATORY operated by UNION CARBIDE CORPORATION for the

RELEASED FOR ANNOUNCEMENT

U.S. ATOMIC ENERGY COMMISSION IN NUCLEAR SCIENCE ABSTRACTS 


\section{DISCLAIMER}

This report was prepared as an account of work sponsored by an agency of the United States Government. Neither the United States Government nor any agency Thereof, nor any of their employees, makes any warranty, express or implied, or assumes any legal liability or responsibility for the accuracy, completeness, or usefulness of any information, apparatus, product, or process disclosed, or represents that its use would not infringe privately owned rights. Reference herein to any specific commercial product, process, or service by trade name, trademark, manufacturer, or otherwise does not necessarily constitute or imply its endorsement, recommendation, or favoring by the United States Government or any agency thereof. The views and opinions of authors expressed herein do not necessarily state or reflect those of the United States Government or any agency thereof. 


\section{DISCLAIMER}

Portions of this document may be illegible in electronic image products. Images are produced from the best available original document. 
Printed in USA. Price $\$ 2.00$. Available from the Clearinghouse for Federal

Scientific and Technical Information, National Bureau of Standards,

U.S. Department of Commerce, Springfield, Virginia

\section{LEGAL NOTICE}

This report was prepared as an account of Government sponsored work. Neither the United States, nor the Commission, nor any person acting on behalf of the Commission:

A. Makes any warranty or representation, expressed or implied, with respect to the accuracy, completeness, or usefulness of the information contained in this report, or that the use of any information, apparatus, method, or process disclosed in this report may not infringe privately owned rights; or

B. Assumes any liabilities with respect to the use of, or for damages resulting from the use of any information, apparatus, method, or process disclosed in this report.

As used in the above, "person acting on behalf of the Commission" includes any employee or contractor of the Commission, or employee of such contractor, to the extent that such employee or contractor of the Commission, or employee of such contractor prepares, disseminates, or provides access to, any information pursuant to his employment or contract with the Commission, or his employment with such contractor. 
Contract No. W-7405-eng-26

ISOTOPES DEVEIOPMENT CENTER

REVIEW OF ISOTOPES TARGET PROGRAM

OCTOBER 1963-DECEMBER 1964

E. H. Kobisk

Isotopes Division

\title{
SEPTEMBER 1965
}

\author{
OAK RIDGE NATIONAL IABORATORY \\ Oak Ridge, Tennessee \\ operated by \\ UNION CARBIDE CORPORATION \\ for the \\ U.S. ATOMIC ENERGY COMMISSION
}




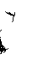

page blank 


\section{SUMMARY}

Activities of the Isotopes Target Center include the preparation of high purity isotopic metals and compounds, participation in special projects such as Operation HENRE and the preparation of ${ }^{239} \mathrm{Pu}$-coated fission chambers, and the development of radioisotope target preparation techniques. Impurity levels of isotopic materials have been reduced and target quality enhanced by improvement of ultrahigh vacuum systems, the use of electronbombardment evaporation and simultaneous reduction-distillation of metals, and the purchase of a new foil-rolling mill.

Ultrahigh vacuum systems were improved by the use of combined titaniumsublimation and ion pumping. Reactive atmospheric gases could be preferentially removed by this system, and pumping speeds were increased as compared with oil diffusion pumping.

Electron-bombardment heating systems were improved for vacuum evaporation of isotopic materials, especially refractory metals and oxides at temperatures between 1500 and $3000^{\circ} \mathrm{C}$. Various filament and crucible configurations as well as ceramic liners were used to enhance vapor beam collimation during production of thin film targets.

Simultaneous reduction-distillation techniques were developed to obtain rare earth metals of high chemical purity which could be rolled into foils with a thickness of $\sim 50 \mu \mathrm{in}$. $\left(\sim 1 \mathrm{mg} / \mathrm{cm}^{2}\right)$. A mixture of the metal oxide and the reductant ( $\mathrm{Al}$, Zr, or $\mathrm{Ta}$ ) in the form of a pressed pellet was reacted in a resistance-heated crucible and the reduced metal was distilled onto a copper substrate.

Special stable isotope targets of germanium and gallium oxide were prepared with film thicknesses of $500 \mu \mathrm{g} / \mathrm{cm}^{2}$ and $50-200 \mu \mathrm{g} / \mathrm{cm}^{2}$, respectively. Preparation techniques for single crystals of silicon of ultrahigh purity were proposed for the fabrication of neutron spectrometer detectors.

The greatest number of radioisotope targets were prepared for Operation HENRE from metal films of titanium or erbium sorbed with tritium. Other radioisotope targets were prepared from fissionable materials such as $\mathrm{Pu}$, $\mathrm{Np}$, U, Al-U alloys, and Th.

During 1964, more than 1200 targets were fabricated not including 500 targets prepared for special contracts such as Operation HENRE. Of these targets, 931 were stable isotope targets, 119 were radioisotope targets, and 168 were tritium targets. 
page blank 
Introduction . . . . . . . . . . . . . . . . . . . . . . . . I

Vacuum Technology . . . . . . . . . . . . . . . . . . . . . . 1

High Temperature Evaporation Technology . . . . . . . . . • . . . . 7

Materials Purification Technology . . . . . . . . . . . . . . . . . 13

Stable Isotope Target Preparations . . . . . . . . . . . . . . . 18

Germanium •. . . . . . . . . . . . . . . . . . . 18

Gallium Oxide . . . . . . . . . . . . . . . . . . . 18

Cadmium . . . . . . . . . . . . . . . . . . . . . . 18

Silicon . . . . . . . . . . . . . . . . . . . . . 19

Rolled Folls . . . . . . . . . . . . . . . . . . 20

Radioisotope Target Preparation . . . . . . . . . . . . . . . 21

Tritium Targets for Operation HENRE . . . . . . . . . . . . . 21

Targets Prepared From Fissionable Isotopes . . . . . . . . . . 29

Plutonium-239 Fission Chambers . . . . . . . . . . . . . . 29

Targets for Cross-Section Measurements . . . . . . . . . 32

Distilled Fissionable Metal Targets . . . . . . . . . . 32

Rolled Foils . . . . . . . . . . . . . . . . . 32

Fabricated Target Data . . . . . . . . . . . . . . . . . 33

References • • • • . . . . . . . . . . . . . . . . . . . . . 37 
REVIEW OF ISOTOPES TARGET PROGRAM OCTOBER 1963-DECEMBER 1964

E. H. Kobisk

\section{INTRODUCTION}

From October 1963 through December 1964, many changes and innovations were made in target-fabrication technology and in the general program. The scope of activities was broadened to include preparation of high-purity isotope metals and compounds, chemical conversions of isotopic materials, and special projects of a singular nature but having long-range applications, and a major emphasis was placed on the preparation of radioisotope targets and other research materials comparable to the already existing stable isotopes target program.

Since the need for isotopic materials is constantly increasing, considerable developmental effort and research must be expended in attempting to fabricate the highly defined forms desired by research scientists. The major areas in which this phase of the program has been directed over the past two years are vacuum technology, high-temperature evaporation technology, materials purification technology, and stable and radioisotope target preparations.

\section{VACUUM TECHNOLOGY}

Many targets are prepared by vacuum evaporation of material with subsequent condensation of vapors as thin films on a substrate from which the films might be removed and used in self-supporting form. To produce isotope targets of highest purity, the lowest possible pressure and the lowest possible level of reactive contaminants must be maintained during evaporation and condensation. When oil diffusion pumped systems are used, oil vapors must be trapped before they can enter the vacuum chamber and contaminate contained materials with carbon and/or silicon during the evaporation-condensation procedures. Residual gases, such as oxygen, nitrogen, carbon dioxide, and water vapor, already in the starting material may also contaminate the final film.

Commercial oil diffusion pumps of convenient size (4-9 in. dia) generally have pumping speeds of 400-2000 liters/sec at the low-pressure intake; these are reduced to 50-1200 liters/sec after the necessary additions of traps and valves. Although the maximum speed is sufficient to handle gases from evaporation of material during target preparation, the use of a pumping system of this size is restricted by size, cost, and extensive time required to reach a pressure of $\sim 10^{-7}$ torr. An evaporator system composed of a 2-in.-dia oil diffusion pump without traps or isolation valves (Fig. I) was devised for glove-box use, but the pumping speed ( 50 liters/sec) was too low to continuously evacuate gas loads during lengthy evaporations. For radioisotope target preparation, reduction of isotope cross contamination during subsequent fabrications can be 


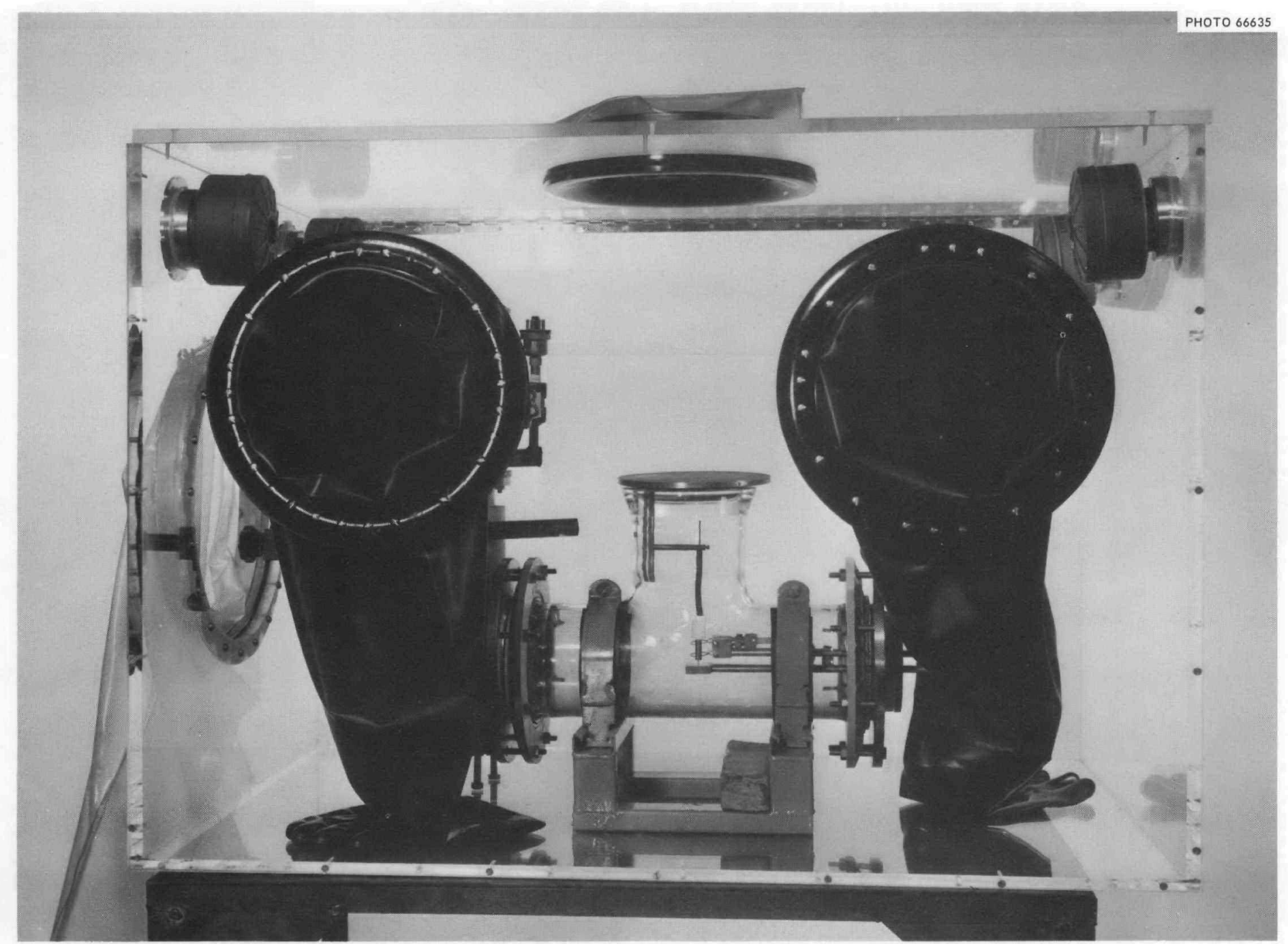

Fig. 1. Oil Diffusion Pumped Evaporator System and Glove Box Enclosure for Radioisotope Target Preparation. 
achieved by either costly decontamination or disposal of the vacuum system. Costs of both of these alternatives are prohibitive if large ( $\geq 4$ in. dia) diffusion pumps, traps, and valves are used. Generally, disposal of small diffusion pumps is the less expensive alternative.

The only commercial pumping systems suitable for replacing the oil diffusion pumps are the sputter-ion pumps. These pumps reduce reactive gases to very low levels, reach vacuum levels of $<10^{-7}$ torr, and can operate at reasonably high pumping speeds (>200 liters/sec) in the vacuum chamber. Gases in these pumps are ionized by an electrical discharge and driven through a high potential drop into titanium metal sheets where they react chemically or are buried interstitially. Titanium metal is simultaneously sputtered from the plates and also reacts with gases in the vicinity. If a titanium-sublimation pump is used in parallel with ion pumping, much greater pumping speeds (>3000 liters/sec) are achieved than from an oil diffusion pump of comparable size. Specific advantages of these combination pumps as compared to oil diffusion pumps are attainment of lower pressures, higher pumping speeds, and decreased residual reactive contaminants

Several systems have been purchased and constructed with combined titaniumsublimation and ion pumping. Although evaluation of these systems, whose maximum capability is $5 \times 10^{-13}$ torr, is not complete, vacuum levels of $\sim 2 \times 10^{-9}$ torr have been reached in the large bakeable system shown in Fig. 2. A small combined titanium-sublimation and ion-pumped system designed from commercial components is shown below the base plate and bell jar in Fig. 3. Although less than one-half the size of a 450-liter/sec diffusion pump, it has a pumping speed of 500 liters/sec. A glass "T" evaporator assembly with a similar pumping system is shown in Fig. 4; this unit will be used for radioisotope target fabrication. The systems in Figs. 3 and 4 routinely pump to vacuum levels of $\sim 10^{-7}$ torr and during evaporations maintain levels of $\sim 3 \times 10^{-6}$ torr, while oil diffusion systems of similar or larger size reach levels $>5 \times 10^{-5}$ torr. A 9-in. diffusion pump with appropriate traps and valves would have slightly better pumping capability than the pumps shown in Figs. 3 and 4; however, the latter systems contain residual gases with fewer molecules of reactive elements (no hydrocarbons or silanes) than the diffusion-pumped systems. 


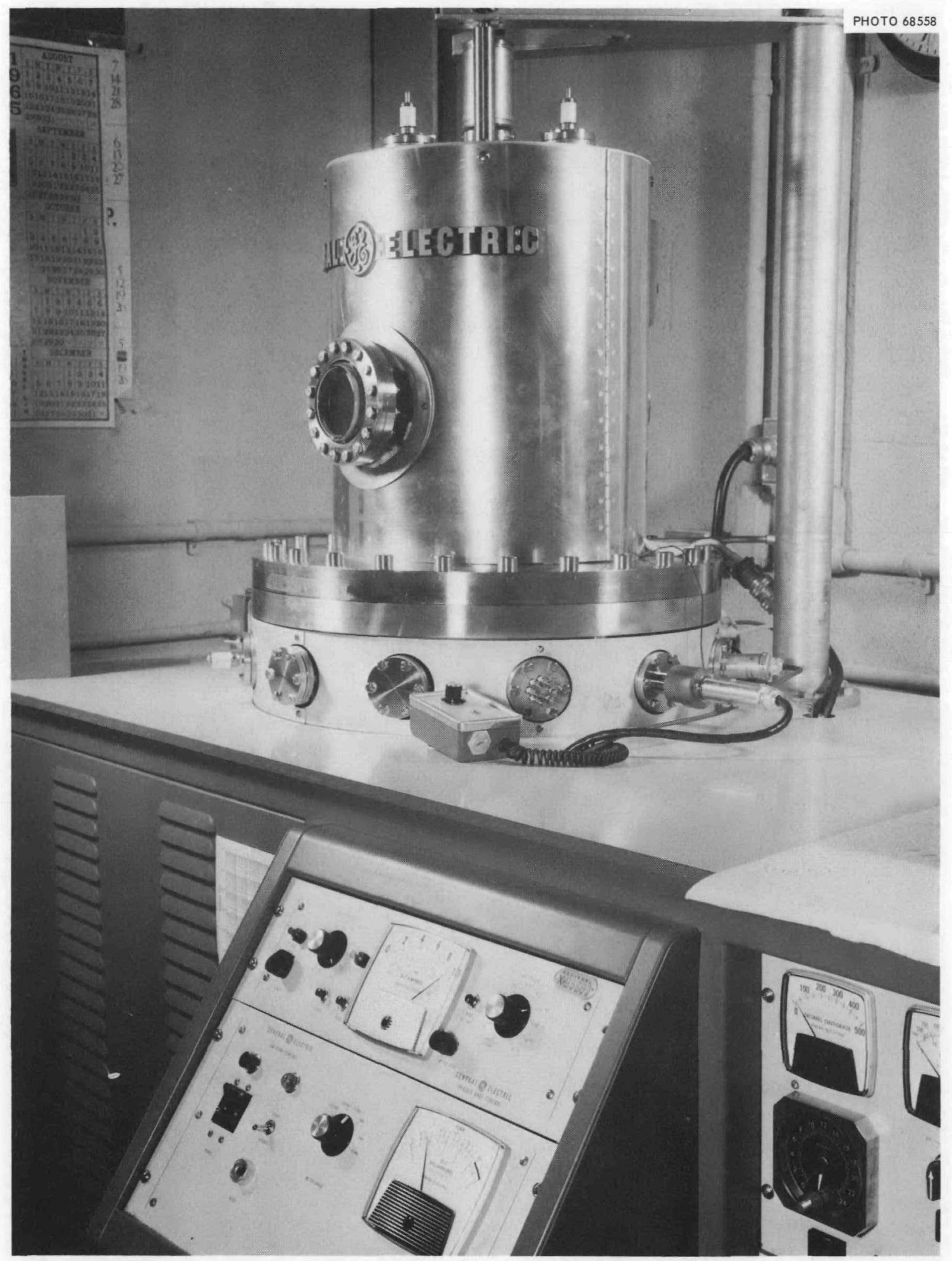

Fig. 2. Bakeable Evaporator System Capable of Achieving Pressure Levels of $5 \times 10^{-13}$ Torr Using Combined Titanium-Sublimation and Ion Pumping. 


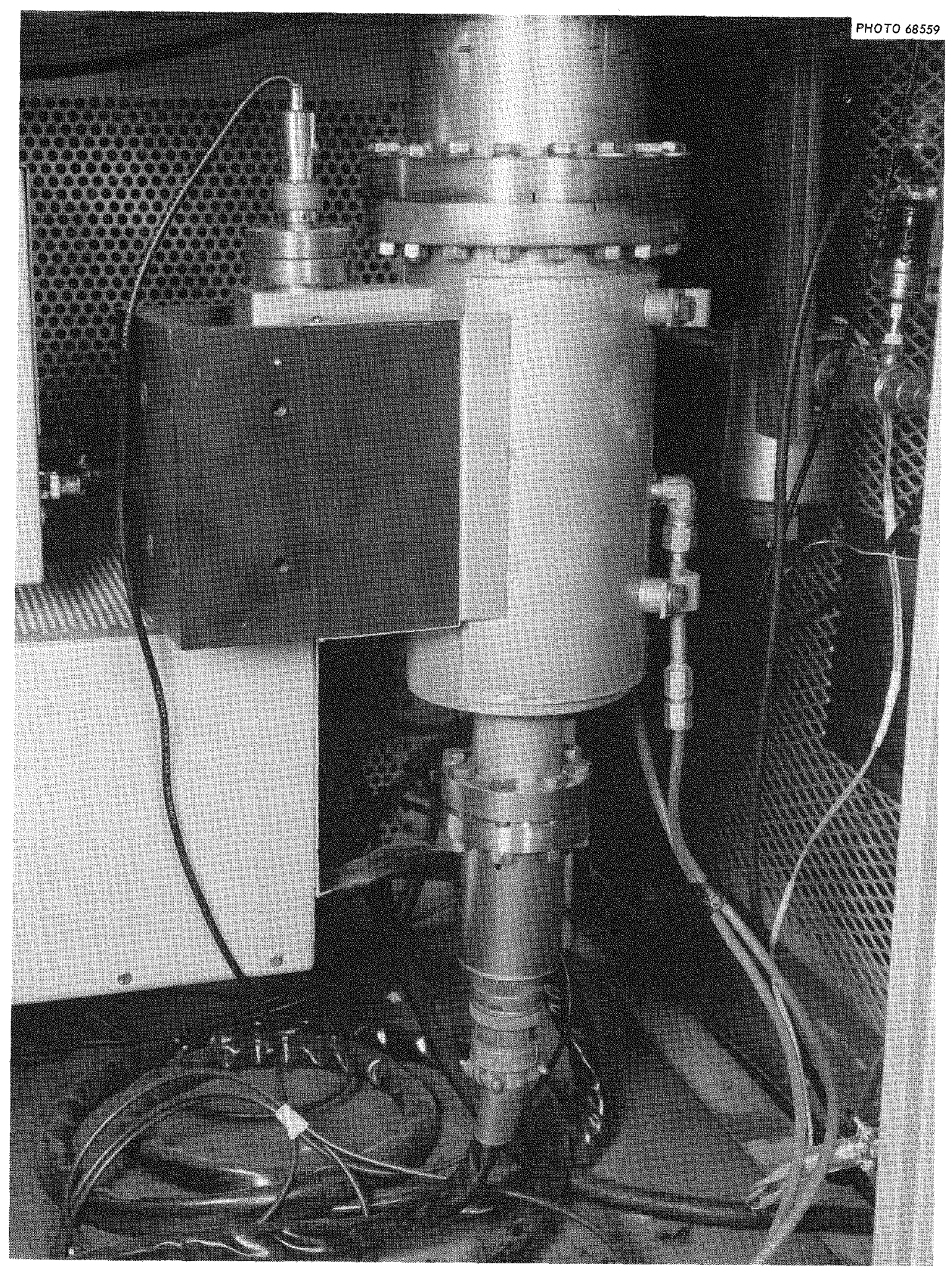

Fig. 3. Combined Titanium-Sublimation and Ion-Pumping System. Pumping speed: 500 liters/sec. 


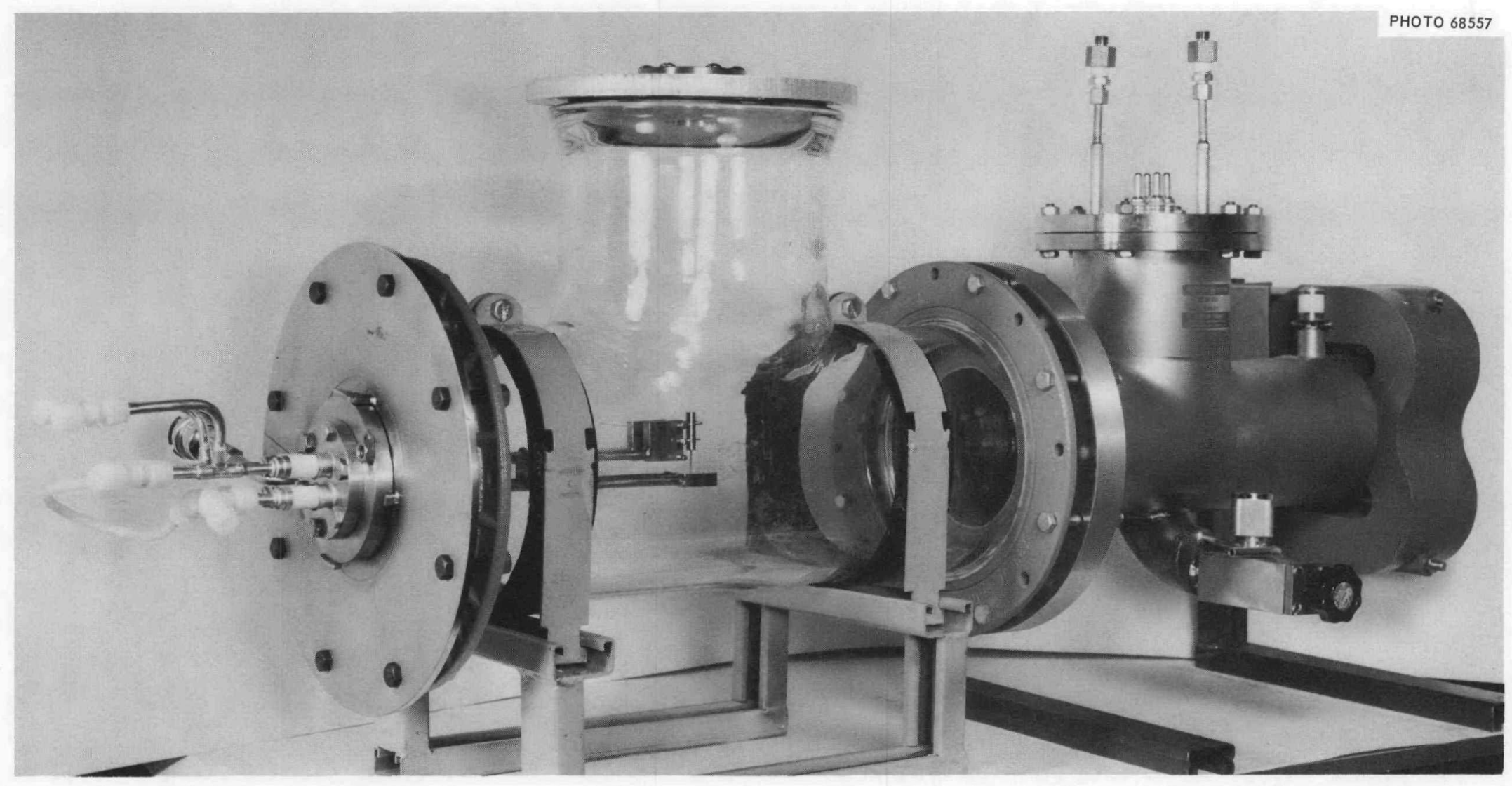

の

Fig. 4. Combined Titanium-Sublimation and Ion-Pumped Evaporator System to be Used in the Preparation of Radioisotope Targets. Pumping speed: 500 liters/sec. 


\section{HIGH TEMPERATURE EVAPORATION TECHNOLOGY}

The following characteristics of an evaporation system are desirable for preparing thin film targets from isotopic materials:

1. Evaporator operation at temperatures from $300-3000^{\circ} \mathrm{C}$.

2. Collimation of vapors for maximum recovery of starting material.

3. Compatibility of evaporant and crucible material to minimize loss of isotope by chemical reaction or alloy formation.

4. Elimination or minimization of contaminants in condensed material.

5. Maximum uniformity of film density.

6. Compatibility of the evaporation system size with vacuum chamber and pumping system.

To achieve as many of these characteristics as possible, various heating techniques were studied; electron bombardment proved most satisfactory for vacuum evaporation of isotopic materials, principally refractory metals and oxides, at temperatures from $1500-3000^{\circ} \mathrm{C}$. A variety of filament and crucible configurations also were designed and preliminary evaluation of the characteristics of each was made.

Schematics of two configurations of electron-bombardment assemblies are shown in Figs. 5 and 6 . The first system ${ }^{1}, 2$ was developed for the evaporation of boron isotopes and normal assay materials; however, most of the evaporant was not recoverable because the vapors subtended a solid angle of $180^{\circ}$. The major advantages of this configuration were reduction of impurities in the condensed films due to the absence of a crucible and the collimation and acceleration of ionized vapors through use of appropriate electrostatic fields.

Since most enriched isotopes are expensive, minimal quantities must be used in order to keep down material costs. To achieve maximum conservation of isotopes, the vaporization system illustrated in Fig. 6 was developed to vaporize a small quantity of isotopic material from a tubular crucible. From the Knudsen laws of gaseous flow through tubes, mechanical collimation and quantitative vaporization of material will result if the tube length is much greater than the internal tube diameter.

The evaporation system design in Fig. 6 met these requirements. Choice of crucible materials was limited to those that would not alloy during fusion and vaporization of the isotope. Figure 7 shows a vaporization gun with ring-type electron-emission filaments fabricated from 20-40 mil thoriated tungsten wire and operated with 25-100 amp AC to achieve the appropriate emission temperatures. Plectrons were drawn from the filaments and directed to the crucible by imposing a positive potential of 100-1000 volts between the crucible and the filaments. Since many electrons did not strike the crucible, the entire assembly was surrounded with 


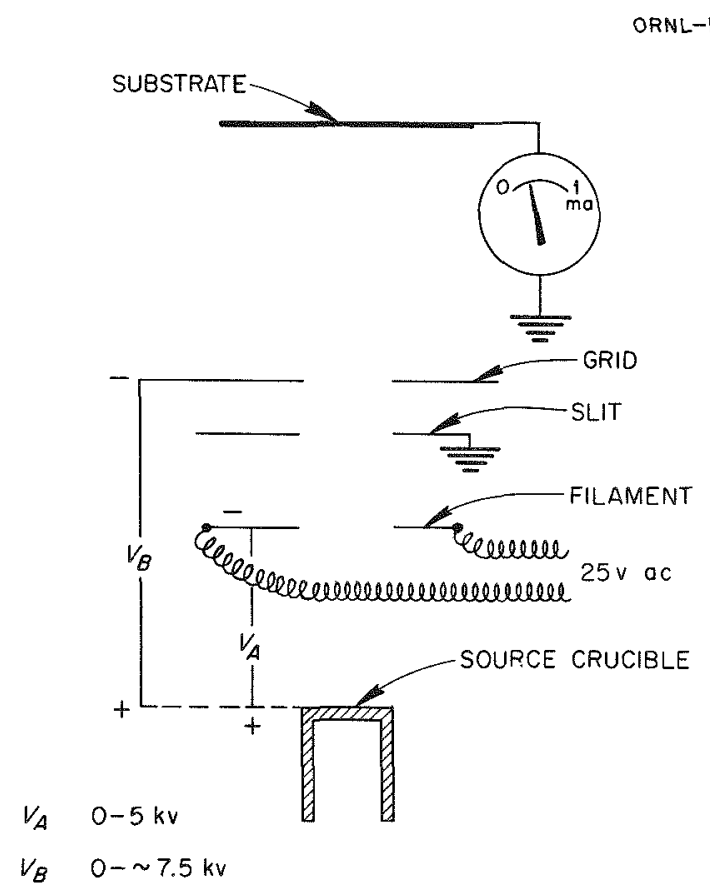

Fig. 5. Schematic of Electron-Bombardment Evaporation and Collimation System Without Surrounding Crucible.

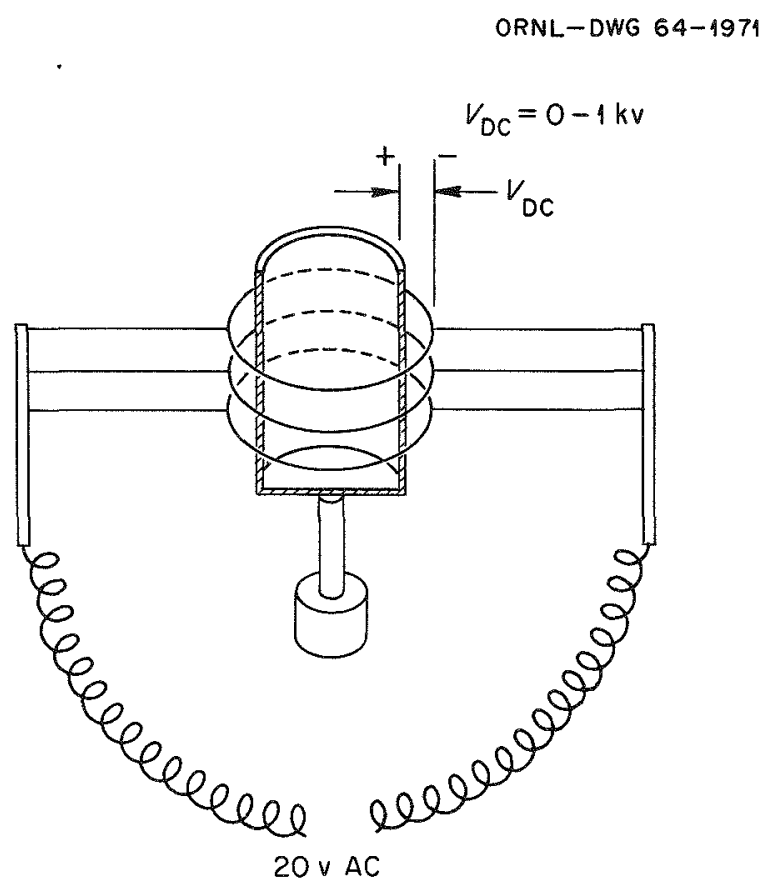

Fig. 6. Schematic of Electron-Bombardment Evaporation System With a Crucible. 


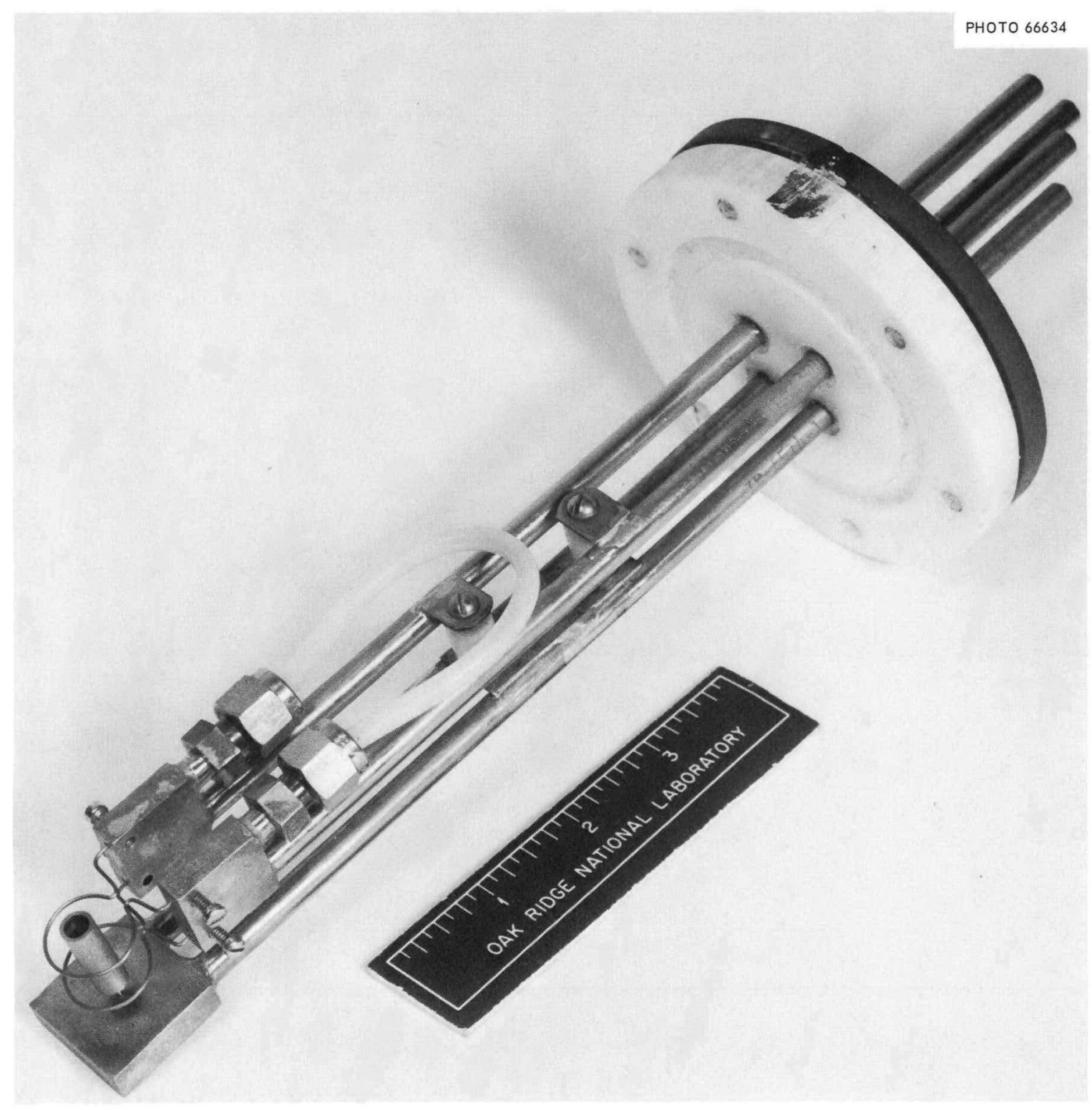

Fig. 7. Electron-Bombardment Heat Source Used for Evaporation From a Tubular Crucible. 
a 0.010 -in.-thick tantalum box which acted as an electrostatic shield and increased the electron current $\sim 30 \%$. To raise the crucible temperature above $2000^{\circ} \mathrm{C}$, an electron current of $\sim 1.5 \mathrm{amp}$ at a potential difference of 800 volts between the filaments and the crucible was required.

Attaining appropriate heat distribution and reducing thermal losses to a minimum were found to be mainly dependent on crucible design. An effective configuration is illustrated in Fig. 8; the crucibles were made from a tungsten rod, 0.75-1.0 in. long. Heat conduction from the crucible to the water-cooled copper support block was limited by a 0.040-in.dia tungsten wire which supported the crucible and resulted in uniform temperature distribution. Crucible materials were usually limited to tungsten, tantalum, and molybdenum due to the high temperatures used. If crucible metal and evaporant were incompatible, ceramic liners (Fig. 9) were used. One of the purest and most versatile materials used for crucibles and liners was spectroscopic graphite.

To collimate vapors even more effectively, the effusion plug shown at the right in Fig. 8 could be inserted. This plug was very effective at short distances between the crucible and the substrate. A comparison of the amount of silver metal deposited using standard evaporation methods (with resistance heating) and electron bombardment as a function of substrate distance from vapor source is shown in Fig. 10. The best collimation (thickest deposit) was obtained by using the Knudsen crucible technique in conjunction with an effusion plug.

A quantitative vapor beam profile was determined for an open Knudsen crucible by measuring the quantity of silver deposited on the surface of a circular substrate with the center coincident with the axis of the tubular crucible. The thickness of the deposit (Fig. II) was determined by counting tracer quantities of ${ }^{1} 1 \mathrm{Om}_{\mathrm{Ag}}$ added to the evaporant and co-deposited on the substrate. The amount of silver deposited, as a function of distance from the vapor source, agreed well with the cosine law in which deposition varies inversely as the square of the distance between the substrate and the source. Since any tendency of the evaporant to creep up the crucible walls leads to multiple evaporation sites, the assumption of evaporation from a point source becomes invalid. Since the crucible used was only 1 in. long with a 0.2 in. i.d., the assumption that the crucible induced Knudsen-type flow of the vapors was probably not valid. Electron-emission filaments were placed near the top and below the midpoint of the crucible to obtain a temperature gradient which would enhance Knudsen flow by reducing multiple evaporation sites and localizing metal creep to the base of the crucible. The tungsten support wire at the crucible base provided heat leakage and aided in establishing the gradient. 


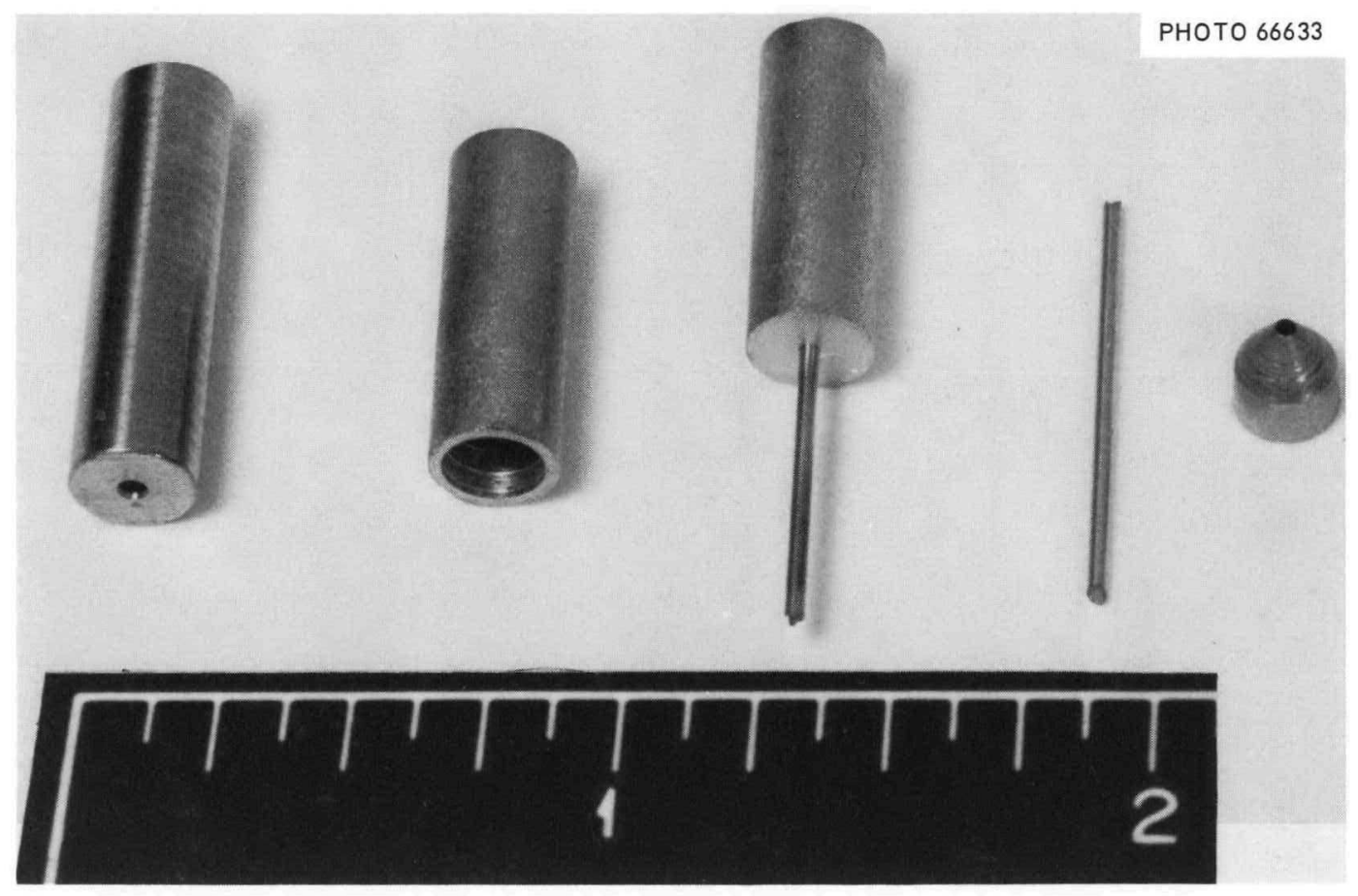

Fig. 8. Tungsten Crucible Components and Effusion Plug (on far right).

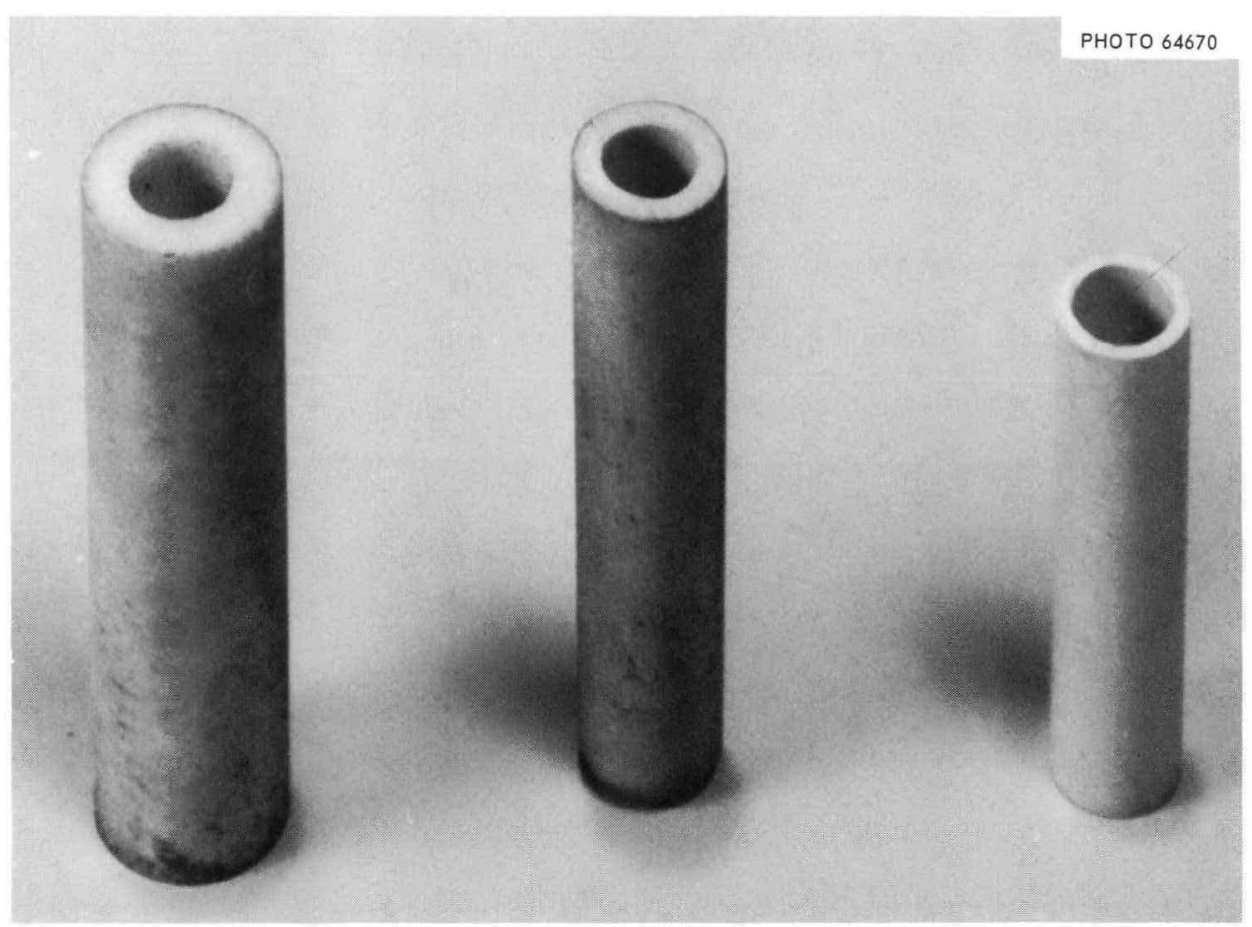

Fig. 9. Ceramic Crucible Liners: (left to right) $\mathrm{BeO}, \mathrm{ZrO}_{2}$, and $\mathrm{BN}$. 


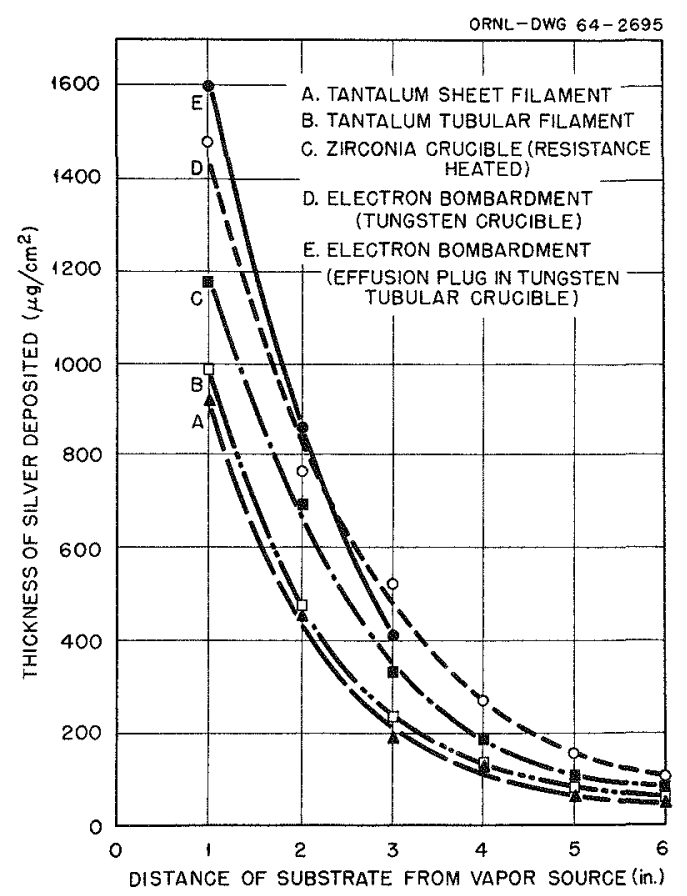

Fig. 10. Effect of Substrate Distance from the Vapor Source on Thickness of Silver Deposits Obtained by Various Evaporation Techniques.

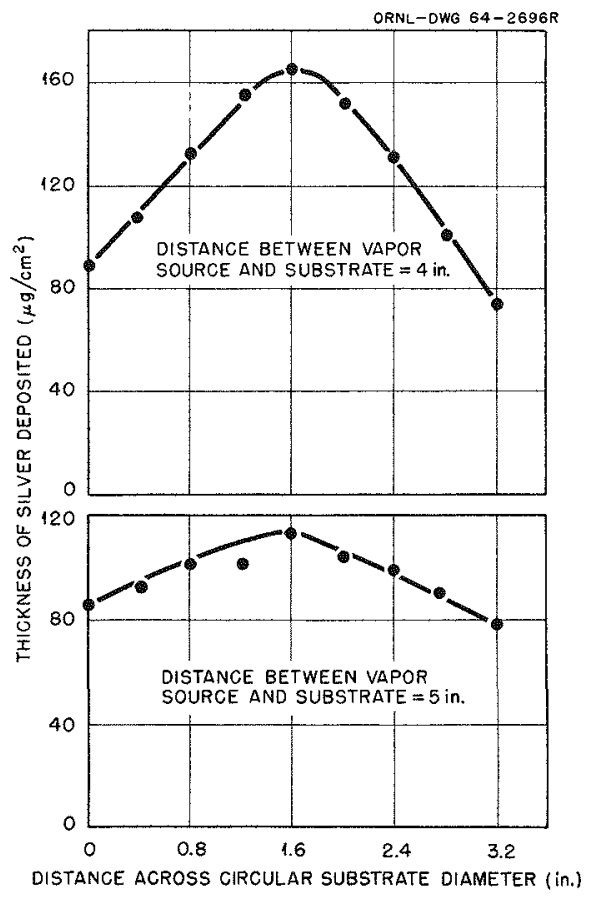

Fig. 11. Comparison of Vapor Beam Density as a Function of Substrate Distance from the Vapor Source Using an Open Tungsten Crucible and Electron Bombardment Heating. 


\section{MATERIAIS PURIFICATION TECHNOLOGY}

Impurities in isotopic material used to study nuclear reactions and properties can cause inaccuracies in resolution by broadening the observed resonances with overlapping peaks of similar energy from other isotopes of the same element or different elements, or by masking of weak resonances of specific nuclei by stronger impurity resonances in the same energy region. The specific number of atoms in a sample must be known for accurate cross-section measurements, and impurity atoms of unknown number and type can adversely affect measurement results. For these reasons, utmost care must be taken to reduce the impurity levels of target materials during preparation.

Oxygen and nitrogen content has been reduced by melting metals in vacuum by electron bombardment heating. Other techniques being developed to enhance chemical purity of isotopes and to form them into targets include zone refining, pyrolytic deposition of metals, and single-crystal growth. Zone refining has limited application because adequate amounts of isotopes are not available. Pyrolytic deposition consists of forming a volatile but thermally unstable compound (usually a metal iodide) of the desired element, vaporizing it to separate it from impurities, and then decomposing the metal iodide on a hot surface. For example, zirconium iodide, formed by direct reaction with elemental iodine at $\sim 350^{\circ} \mathrm{C}$, is volatilized in a chamber containing an electrically heated tungsten filament at $\sim 1200^{\circ} \mathrm{C}$; purified zirconium metal is deposited, and the iodine returns to the impure zirconium metal reservoir to react again. This technique works only where the impurity does not form a volatile iodide. Pyrolytic decomposition can also occur by chemically reacting a volatile compound with a gaseous reducing agent at a heated surface, for example:

$$
W F_{6 \uparrow}+3 \mathrm{H}_{2 \uparrow} \Leftrightarrow W \downarrow+6 \mathrm{HF}
$$

Chemical purity can also be achieved by using the single-crystal growth technique. The Bridgeman process avoids the use of a seed crystal and is useful where strict preservation of isotopic purity is required.

The feasibility of growing $\mathrm{CsCl}$ by the Czochralski technique using a seed crystal was determined. Single crystals of ${ }^{137} \mathrm{CsCl}$ will be prepared to study the self-sintering properties of crystals joined on clean crystal faces under low contact pressures when normal CsCl seed crystals have been obtained and remote handling techniques for crystal growth within a cell enclosure have been developed. Observations of polycrystalline ${ }^{137} \mathrm{CsCl}$ powder indicate that sintering takes place, but the mechanism is unknown.

Vacuum reduction of oxides to metals with simultaneous distillation of the product and finally condensation onto a cold substrate, using electron bombardment heating and various reductants, has been studied as a possible technique for preparation of the rare-earth metal isotopes. These metals may then be formed into targets by rolling into foils of suitable thicknesses to be used in accelerators. Isotopes of rare earths as metals had previously been unobtainable. 
Oxide reduction at high temperature was first attempted in order to obtain magnesium isotopes either in bulk quantity or thin-film form. Powdered MgO was mixed with a slight stoichiometric excess of aluminum powder and heated by a tantalum filament to $\sim 1100^{\circ} \mathrm{C}$. Magnesium was produced by the following reaction:

$$
3 \mathrm{MgO}+2 \mathrm{~A} \perp \rightarrow 3 \mathrm{Mg} \uparrow+\mathrm{A}_{2} \mathrm{O}_{3}
$$

The simple resistance filament, however, caused excessive loss of material and contamination of the distillate with aluminum, whose vapor pressure becomes significant at $>1020^{\circ} \mathrm{C}$. The filament geometry prevented temperature control.

Box ${ }^{3}$ devised a magnesium still for preparing large quantities of metal by a one-step reduction-distillation process. To obtain high yields of magnesium, a temperature of $>1250^{\circ} \mathrm{C}$ was required to induce reduction of the powdered magnesium oxide and subsequent distillation of the metal. At this temperature, however, aluminum contamination was appreciable $>0.3$ wt of. Also, the magnesium metal was difficult to remove from the cold-finger condenser. Although this distillation process was a considerable improvement over the filament technique described above, greater product purity and a more compact condensate were required.

To obtain a high-purity product at a lower distillation temperature, several resistance heating methods were studied. A mixture of powdered $\mathrm{MgO}$ and a 100\% stoichiometric excess of aluminum powder in the form of a pressed pellet was placed in a tantalum crucible (shown in Fig. 12) to achieve intimate contact of reactants and to obtain better heat conduction. Since the pellet retained its configuration during reaction, handling problems and crucible contamination were reduced. A cap with a 0.040-in.-dia effusion port was placed on the crucible to collimate the vapors. The crucible was heated resistively with low-voltage, highcurrent $A C$ power; the crucible temperature was measured with a chromelalumel thermocouple, spot-welded to the crucible wall. Reduction occurred. at $\sim 1018^{\circ} \mathrm{C}$ with simultaneous distillation of the product. The metal distillate could be condensed onto a glass plate substrate and removed by peeling without a parting agent or exposure to water. By using a lower temperature $\left(\sim 230^{\circ} \mathrm{C}\right.$ lower $)$ and a pressed pellet as the reaction mixture, a high-purity product ( 200 ppm of aluminum) was obtained in a more compact form.

To obtain the bulk material, a water-cooled copper substrate was placed over the effusion port $\sim 1 / 16$ in. from the cap. As the metal distilled out of the crucible, a stalactitic growth formed on the substrate blocking the effusion port. Continued distillation of metal inside the plugged crucible formed a crystalline deposit inside the cap as an extention of the stalactite. The polycrystalline nature of the magnesium "flowers" 


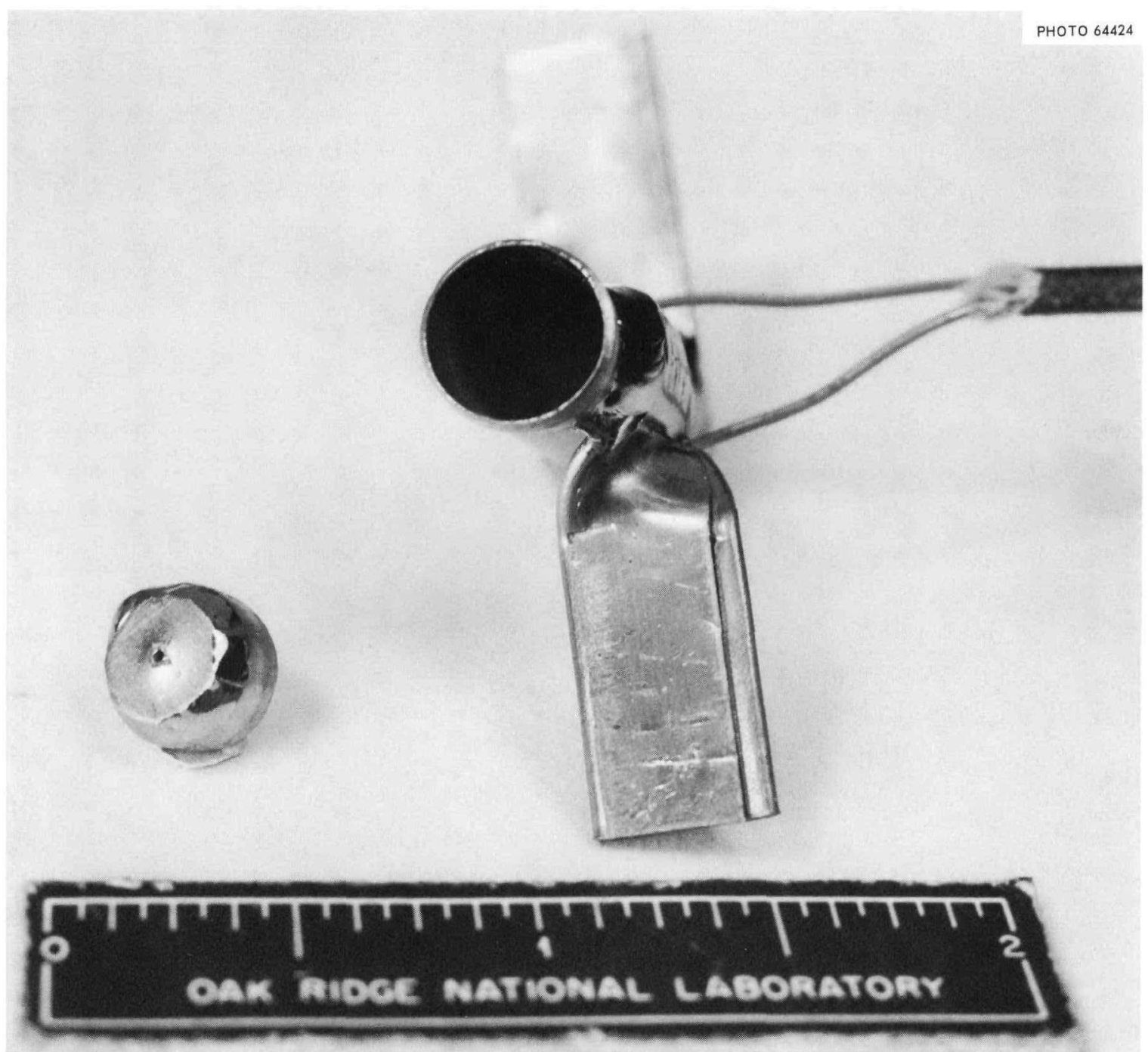

Fig. 12. Tantalum Crucible and Collimation Cap for Resistance Heat Source. 
can be seen in Fig. 13. Extremely high-purity metal was obtained in this manner because the deposits were grown in an atmosphere of the metal vapor after exclusion of oxygen, nitrogen, and other residual gases during the initial growth of the stalactite on the substrate. Although activation analyses have not been performed on this metal, the purity level is such that foils of magnesium can be prepared by cold rolling a feat performed on normal magnesium only in the case of very high purity.

The condensation zone for the magnesium metal distillate was maintained at a lower temperature than the reaction zone, but the condensation temperature had to be elevated to $600-700^{\circ} \mathrm{C}$ to attain the flower configurations. If the temperature was too low, growth did not occur; instead, the entire cap of the crucible became coated with metal. Single-crystal growth could be achieved, but the narrow temperature interval was difficult to maintain because of changes in heat dissipation in the crystal as it became larger. A single $\sim 6-m$-dia crystal of ${ }^{24} \mathrm{Mg}$ was grown in this manner.

Rare-earth metals of high isotopic purity have been prepared by this technique and rolled into thin foils ( $\sim \mathrm{mg} / \mathrm{cm}^{2}$ areal density or $\sim 50 \mu$ in. thickness). Figure 14 illustrates flowers, pressed pellets, and a rolled foil of ytterbium metal produced in this manner. Rare-earth metals successfully prepared by reduction-condensation with $\leq 500$ ppm of reductant are $\mathrm{Eu}, \mathrm{Gd}, \mathrm{Ho}, \mathrm{Er}, \mathrm{Yr}$, and $\mathrm{Iu}$. The reductant used for each of these metal oxides is given below:

Metal Oxide

$$
\begin{aligned}
& \mathrm{Eu}_{2} \mathrm{O}_{3} \\
& \mathrm{Cr}_{2} \mathrm{O}_{3} \\
& \mathrm{Ho}_{2} \mathrm{O}_{3} \\
& \mathrm{Er}_{2} \mathrm{O}_{3} \\
& \mathrm{Yb}_{2} \mathrm{O}_{3} \\
& \mathrm{Lu}_{2} \mathrm{O}_{3}
\end{aligned}
$$

\section{Reductant}

Aluminum powder

Zirconium powder

Tantalum filings

Zirconium powder

Aluminum powder

Zirconium powder

The selection of reductant becomes more important as higher distillation temperatures are required in order to minimize contamination of the metal with codistilled reductant.

Calcium metal isotopes have also been prepared as flowers using aluminum or lanthanum as reductants. A lengthy distillation at the lowest feasible temperature was required to keep aluminum contamination to a minimum. A ${ }^{42} \mathrm{Ca}$ foil, 1 by $I$ in. ( $1 \mathrm{mg} / \mathrm{cm}^{2}$ ), was prepared by reducing $50 \mathrm{mg}$ of ${ }^{42} \mathrm{CaO}$ with aluminum, condensing the metal, and cold-rolling in an argon atmosphere. 


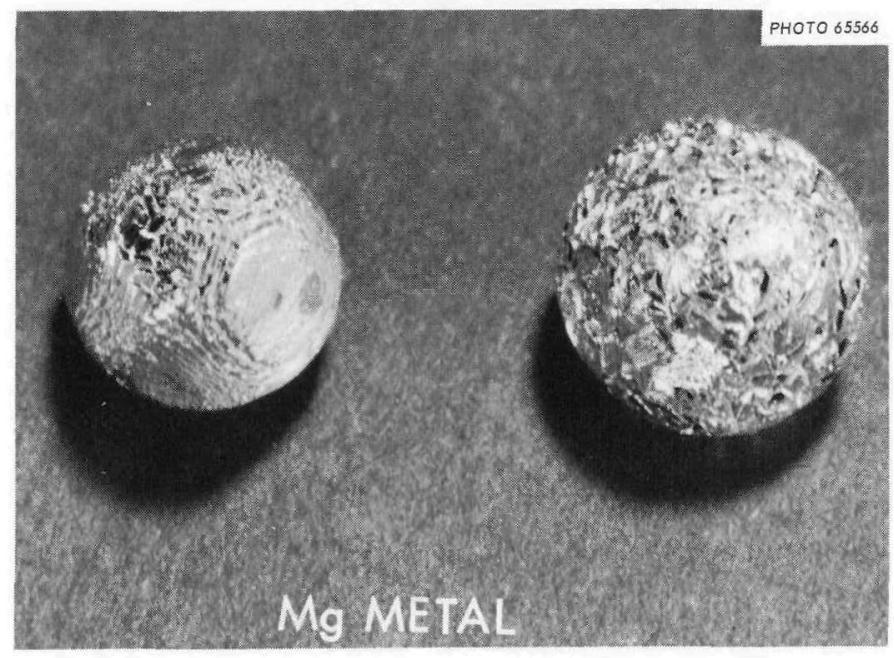

Fig. 13. Polycrystalline Magnesium "Flowers" Prepared by Simultaneous Reduction-Distillation.

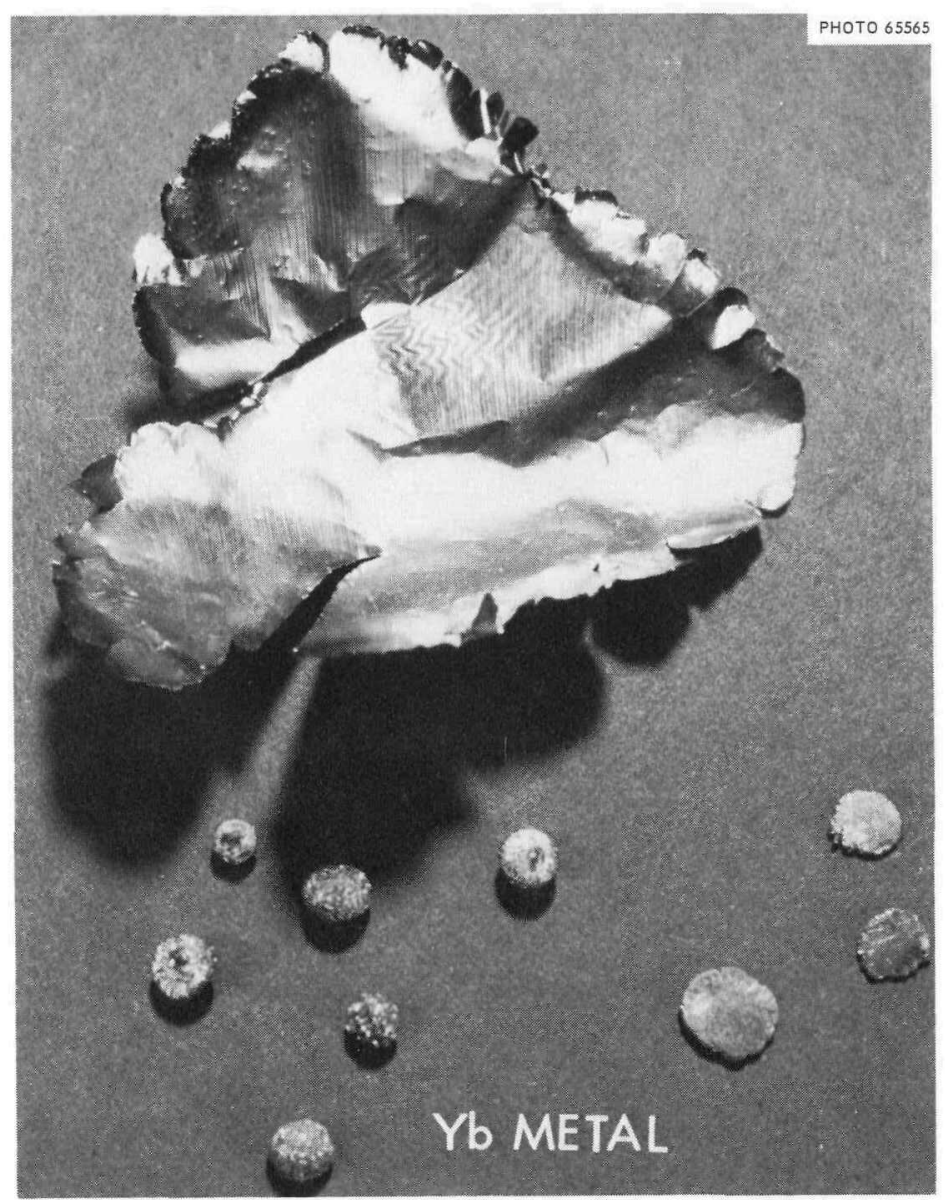

Fig. 14. Pressed Pellets, Flowers, and Rolled Foil of Ytterbium Metal Prepared by Simultaneous Reduction-Distillation. 


\section{STABIE ISOTOPE TARGET PREPARATIONS}

\section{Germanium}

A satisfactory method of producing self-supporting films of germanium isotopes by evaporation has not been found, although significant progress has been achieved. A graphite crucible heated by electron bombardment provided thermal control during evaporation, but many pinholes formed in the condensed film. Recent studies indicated that hot sparks of graphite formed during electron bombardment and the release of gaseous impurities left these holes and prevented crystal growth during film formation by inclusion of these impurities in the growing film.

Excellent results have been obtained using a boron nitride liner (outgassed at $>1800^{\circ} \mathrm{C}$ ) in a tungsten crucible to avoid the detrimental effects obtained with a graphite crucible. Uniform germanium films were obtained by condensation on chrome-plated stainless steel substrates coated with $\mathrm{NaCl}$ as the parting agent. At film thicknesses of $\sim 500 \mu \mathrm{g} / \mathrm{cm}^{2}$, the ductile foil could be easily manipulated and mounted; however, at thicknesses $>500 \mu \mathrm{g} / \mathrm{cm}^{2}$ the films cracked during removal from the substrate. Strain, induced during condensation, was evidenced by the tendency of the film to curl inward toward the substrate.

Perfect crystal growth, with deposit thickness limited to a few hundred angstroms, has been attained at substrate temperatures between $350-1200^{\circ} \mathrm{C}$ using polished single-crystal germanium substrates. Further studies of germanium deposited onto single crystals of salts are needed to determine the feasibility of high-temperature crystal growth and film stripping in the thickness range of $500-1500 \mu \mathrm{g} / \mathrm{cm}^{2}$.

\section{Ga.llium Oxide}

Since the low melting point $\left(30^{\circ} \mathrm{C}\right)$ of gallium metal prevents the formation of self-supporting metal films, gallium oxide was evaporated and condensed onto a thin $\left(50 \mu \mathrm{g} / \mathrm{cm}^{2}\right)$ carbon substrate. Homogeneous films of the oxide were difficult to obtain, even on metal substrates, because of complex outgassing problems. Gallium forms at least two oxides $\mathrm{Ga}_{2} \mathrm{O}$ and $\mathrm{Ga}_{2} \mathrm{O}_{3}$ - which have different vaporization and sublimation temperatures. The monoxide sublimes at $\sim 500^{\circ} \mathrm{C}$ which would make it ideal for deposition in thin-film form but, unfortunately, some of the monoxide disproportionates upon evaporation and eventually a residue of the sesquioxide results. Vigorous gas evolution accompanying the sublimation of the monoxide caused spattering of the powder with subsequent loss of material and destruction of the substrate. The most satisfactory method was evaporation of the sesquioxide at $\sim 1500^{\circ} \mathrm{C}$. Targets having an oxide thickness of $50-200 \mu \mathrm{g} / \mathrm{cm}^{2}$ were prepared in this manner.

Cadmium

The formation of cadmium metal isotopes into thin-film form was difficult due to its comparatively low vaporization temperature $\left(320^{\circ} \mathrm{C}\right.$ at $0.10 \mathrm{~mm}$ of $\mathrm{Hg}$ ). The vapor tends to bounce from the substrate even when water-cooled. 
In a diffusion-pumped evaporator, cadmium would not deposit at distances less than 6 in. from the vaporization source because of the high vapor. pressure. Variation of substrate material and substrate cleaning procedures, including argon-bombardment etching (flow discharge), did not eliminate vapor reflection.

Evaporation of cadmium at vacuum levels of $10^{-8}$ torr, obtained by combined titanium-sublimation and sputter-ion pumping, indicated that cadmium vapor would stick to a clean substrate. Vapor reflection in the diffusion-pumped systems was probably due to contamination of the substrate surface by oil and/or cracked-oil products, or by residual gas oxidation at pressures of $\sim 10^{-5}$ torr.

\section{Silicon}

A proposal has been developed for preparing ultrahigh purity single crystals of silicon to be used for fabrication of solid-state detectors for neutron spectrometers. The background noise level of these spectrometers could be reduced by a factor of ten using $3 \mathrm{O}_{\mathrm{Si}}$ crystals. The use of ${ }^{29_{\mathrm{Si}}}$ crystals for neutron spectra determinations in the energy range of $4-8 \mathrm{MeV}$ using the ${ }^{29_{\mathrm{Si}}(n, \alpha)}{ }^{26} \mathrm{Mg}$ reaction has also been proposed. Both isotopes are also needed for transistors and diodes for space applications and solid-state-physics research. The desired impurity level of these crystals is $\sim 10^{-13}$ at. $\%$. For this purpose a total of $100 \mathrm{~g}{ }^{29} \mathrm{Si}$ and $150 \mathrm{~g}$ ${ }^{30} \mathrm{Si}$ has been separated.

The procedure for preparing single crystals of silicon isotopes differs markedly from commercial processes because of the extreme care requixed to preserve the isotopic assay of the starting material. The proposed theoretical reactions, using isotopic $\mathrm{SiO}_{2}$ (only chemical form available after calutron separation and processing) as starting material, are the following:

$$
\begin{aligned}
& \mathrm{SiO}_{2}+2 \mathrm{~F}_{2} \Leftrightarrow \mathrm{SiF}_{4} \uparrow+\mathrm{O}_{2} \text {, } \\
& \mathrm{SiF}_{4}+4 \mathrm{IiH} \Leftrightarrow \mathrm{SiH}_{4}+4 \mathrm{LiF} \\
& \mathrm{SiH}_{4} \Leftrightarrow \mathrm{Si}+2 \mathrm{H}_{2} \text {. }
\end{aligned}
$$

In reaction 1 , elemental fluorine reacts with $\mathrm{SiO}_{2}$ in a nickel apparatus of all-welded construction. Theoretical yields of $\mathrm{SiF}_{4}$ should be obtainable and chemical and isotopic contamination of silicon should be minimized, if not entirely avoided, by pretreatment of the nickel system with fluorine. In reaction 2, silicon is chemically purified by the action of a molten salt bath composed of an eutectic mixture of $\mathrm{LiCl}, \mathrm{KCl}$, and $\mathrm{IiH}$ (or $\mathrm{IiAlH}_{4}$ ) held at $400^{\circ} \mathrm{C}$ in which all interfering hydrides ( $\mathrm{PH}_{3}, \mathrm{AsH}_{3}$, etc.) are decomposed. The silane $\left(\mathrm{SiH}_{4}\right)$ obtained should be of very high purity and yield, with little change in isotopic composition. 
Thermal decomposition of silane to silicon metal (reaction 3) is expected to generate a polycrystalline or single-crystal bar of the separated isotope. In a water-cooled quartz chamber, a wafer of tungsten or carbon will be supported on a rod (nonsusceptor) which can be rotated and withdrawn at a predetermined rate. Radiofrequency heating from outside the chamber will heat the susceptor to a temperature of $\sim 1300^{\circ} \mathrm{C}$ to initiate decomposition of silane. A jet of silane at a pressure of $\sim 9 \mathrm{~mm} \mathrm{Hg}$ will be impinged onto the heated surface with an estimated yield of $90-95 \%$ silicon metal. Nozzle design, distance of the nozzle from the susceptor, field coil geometry, rotation, and withdrawal rates will be adjusted to obtain maximum yield.

After a small polycrystalline deposit of silicon is formed on the susceptor, a single-crystal bax may be generated by increasing the temperature of the silicon deposit to its melting point and continuously decomposing silane. As the bar moves out of the heat zone, the silicon should form a monocrystal or large polycrystals. All effluent gases (a mixture of unreacted $\mathrm{SiH}_{4}$ and $\mathrm{H}_{2}$ ) can be trapped ${ }^{4,5}$ or chemically burned so that the $\mathrm{SiH}_{4}$ may be recycled in the system.

If polycrystalline material is obtained, float-zone refining will be necessary with appropriate seeding for single-crystal growth. The float-zone procedure is time consuming and isotopic contamination by the seed crystal (normal silicon) may occur. Seed crystals of the isotope will be obtained by appropriate orientation and cutting of the large polycrystalline bars. Either electron bombardment or radiofrequency heating will be used to float-zone the silicon. Little or no contamination of isotopic purity should be incurred from construction materials in either the thermal decomposition of silane or in the float-zone procedure.

Analytical methods which are useful in determining the purity of the crystalline bars are spark-source spectroscopy, emission spectroscopy, and resistivity measurement (desired level $>3000 \mathrm{ohm}-\mathrm{cm}$ ). Only after the crystals are formed can the impurity level be ascertained. With the proposed silane process, a purity level should be possible which meets or exceeds the required chemical impurity of $\sim 10^{-13}$ at. $\%$.

\section{Rolled Foils}

A new 8-in. rolling mill significantly improved the quality, uniformity, and minimum thickness to which isotope foils could be rolled. The mill is a four-high type using 1.5-in.-dia work rolls in contrast to the 1.75-in.-dia work rolls of the original mill employed for this purpose. The DC drive of the new mill allows continuous variation of roll speeds whereas the other mill, being gear driven, has only one speed. Nickel foils can now be rolled to thicknesses of $\sim 250 \mu \mathrm{g} / \mathrm{cm}^{2}$ instead of $1 \mathrm{mg} / \mathrm{cm}^{2}$. Cartridge heaters axially located in the backing rolls enable materials to be rolied at temperatures up to $400^{\circ} \mathrm{C}$.

This mill will eventually be housed in a glove box containing a purified argon atmosphere so that reactive metals, particularly radioactive materials such as $\mathrm{Pu}, \mathrm{Np}, \mathrm{U}$, and $\mathrm{Am}$, can be rolled. 


\section{RADIOISOTOPE TARGET PREPARATION}

\section{Tritium Targets for Operation HENRE}

Development of a 14-in.-dia tritium target for use as a neutron source, under bombardment with deuterons, has been a principal part of the Target Center program. This target will be used in conjunction with an accelerator being designed by the Thermonuclear Division. The objective of the program, Operation HENRE (High Energy Neutron Reactions Experiment), is to study the effects of high-energy (14-Mev) neutrons on natural environment. The neutron yield has been designated as $>10^{13}$ neutrons $/ \mathrm{sec}$ for a continuous period of $4 \mathrm{hr}$. The only feasible reaction to achieve these conditions was the ${ }^{3} \mathrm{H}(\mathrm{d}, \mathrm{n})^{4} \mathrm{He}$ reaction.

The neutron output of tritium-sorbed targets bombarded by $150-\mathrm{kev}$ deuterons is determined by the concentration of tritium atoms at the target surface (only atoms within the first $\sim 75-\mathrm{kev}$ thickness are effective in producing neutrons) and by the amount of beam energy attenuation characteristic of the metal film. The first of these criteria is governed by the stopping coefficient of the metal for deuterons and the mobility of tritium atoms in the metal. The second criterion depends upon the chemical stoichiometry of a stable tritium-metal combination. A more stable target is attained when the tritium is chemically combined with the metal sorber. Heats of formation $\left(\Delta \mathrm{H}_{\mathrm{f}}\right.$ ) of various metal hydrides and the stoichiometry of the respective compounds are given in Table 1. The most stable compounds listed are those with the highest $\Delta \mathrm{H}_{\mathrm{f}}$ values - the rare earths, $\mathrm{Y}, \mathrm{Zr}$, Ti, Sc, Ca, and Sr. Several chemical and physical properties of the more stable hydrides prevent their application as neutron sources. Calcium and strontium hydrides are too reactive with atmospheric gases to be considered suitable target materials, since gaseous tritium or tritiated water would result. Targets for Operation HEIRE must be able to withstand handling and limited storage in the atmosphere. Many of the rare-earth-metal hydrides are also too reactive and only $\mathrm{Pr}$, No, Ho, and Er appear to be satisfactory.

Since the number of neutrons generated under deuteron bombardment is directly proportional to the number of tritium atoms available for reaction, the highest possible ratio of tritium-to-metal atoms is necessary to reach maximum neutron output. Metal hydrides having tritium-to-metal ratios in excess of $1: 1$ were considered first. Criteria of chemical reactivity with atmospheric gases, chemical stability of the metal hydrides, and the tritium-to-metal atom ratio indicated that $\mathrm{Y}^{3} \mathrm{H}_{2}, \mathrm{Zr}^{3} \mathrm{H}_{\mathrm{X}}, \mathrm{Ti}^{3} \mathrm{H}_{\mathrm{X}}, \mathrm{Pr}^{3} \mathrm{H}_{2}$, $\mathrm{Nd}^{3} \mathrm{H}_{2}$, $\mathrm{Ho}^{3} \mathrm{H}_{2}$, and $\mathrm{Er}^{3} \mathrm{H}_{2}$ should be studied. Of this group $\mathrm{Y}^{3} \mathrm{H}_{2}, \mathrm{Zr}^{3} \mathrm{H}_{\mathrm{X}}$, $\mathrm{Ti}^{3} \mathrm{H}_{\mathrm{X}}$, and $\mathrm{Er}^{3} \mathrm{H}_{2}$ have been evaluated.

Targets were prepared for evaluation by vacuum evaporation of the pure metal and subsequent condensation of the vapors onto a clean copper or platinum substrate. The target was then removed from the evaporation system and placed in a tritium sorption system. After the system was evacuated, the target was exposed to tritium gas at a pressure of $\sim 40 \mathrm{~cm}$ Hg and simultaneously heated to $450^{\circ} \mathrm{C}$. Upon cooling, the condensed metal film sorbed tritium both interstitially and by chemical reaction. 
Table 1. Heats of Formation of Metal Hydrides*

\begin{tabular}{|c|c|c|c|}
\hline Hydrides & $\begin{array}{c}\mathrm{\Delta H}_{\mathrm{f}} \text {, } \\
\mathrm{kcal} / \mathrm{mole} \text { of } \mathrm{H}_{2}\end{array}$ & $\begin{array}{c}\text { Rare earth } \\
\text { hydrides }\end{array}$ & $\begin{array}{c}\Delta \mathrm{HH}_{\mathrm{f}}, \\
\mathrm{kcal} / \mathrm{mole} \text { of } \mathrm{H}_{2}\end{array}$ \\
\hline IIHE & 36.6 & $\mathrm{LaH}_{2}$ & 49.6 \\
\hline$L i^{2} \mathrm{H}$ & 34.1 & $\mathrm{La}^{2} \mathrm{H}_{2}$ & 46.6 \\
\hline $\mathrm{Li}^{3} \mathrm{H}$ & 32.2 & $\mathrm{CeH}_{2}$ & 49.2 \\
\hline $\mathrm{NaIH}$ & 27.3 & $\mathrm{Ce}^{2_{\mathrm{H}_{2}}}$ & 46.3 \\
\hline $\mathrm{Na}^{2} \mathrm{H}$ & 33.5 & $\mathrm{PrH}_{2}$ & 50.0 \\
\hline $\mathrm{KH}$ & 28.4 & $\mathrm{Pr}^{2} \mathrm{H}_{2}$ & 48.0 \\
\hline $\mathrm{K}^{2} \mathrm{H}$ & 28.9 & $\mathrm{NdH}_{2}$ & 50.4 \\
\hline $\mathrm{RbH}$ & 20.7 & $\mathrm{GdH}_{2}$ & 51.4 \\
\hline $\mathrm{Rb}^{2} \mathrm{H}$ & 12.2 & $\mathrm{TbH}_{2}$ & 51.8 \\
\hline $\mathrm{CsH}$ & $15 \cdot 9$ & $\mathrm{~Tb}^{2} \mathrm{H}_{2}$ & 49.6 \\
\hline $\mathrm{CS}_{\mathrm{S}}{ }^{2} \mathrm{H}$ & 12.4 & $\mathrm{DyH}_{2}$ & 55.4 \\
\hline $\mathrm{CaH}_{2}$ & 49.8 & $\mathrm{Dy}^{2} \mathrm{H}_{2}$ & $52 \cdot 2$ \\
\hline $\mathrm{SrH}_{2}$ & 47.6 & $\mathrm{HOH}_{2}$ & 55.4 \\
\hline $\mathrm{BaH}_{2}$ & $29 \cdot 5$ & $\mathrm{H}^{2} \mathrm{H}_{2}$ & 53.2 \\
\hline $\mathrm{ScH}_{2}$ & 41.4 & $\mathrm{ErH}_{2}$ & 55.2 \\
\hline $\mathrm{YH}_{2}$ & 54.1 & $\mathrm{E}^{2}{ }^{2} \mathrm{H}_{2}$ & $52 \cdot 2$ \\
\hline$Y^{2} \mathrm{H}_{2}$ & 51.7 & $\mathrm{TmH}_{2}$ & 53.8 \\
\hline $\mathrm{TiH}_{I .4}$ & 39.5 & $\mathrm{Tm}^{2} \mathrm{H}_{2}$ & 51.5 \\
\hline $\mathrm{ZrH}_{I .4}$ & 49.7 & $\mathrm{LuH}_{2}$ & 49.1 \\
\hline $\mathrm{HfH}_{1} \cdot 6$ & 34.5 & $\mathrm{Iu}^{2} \mathrm{H}_{2}$ & $47 \cdot 3$ \\
\hline $\mathrm{ThH}_{2}$ & 34.4 & & \\
\hline $\mathrm{UH}_{3}$ & 20.6 & & \\
\hline
\end{tabular}

* P. M. S. Jones, J. SouthaII, and K. Goodhead, The thermaI stability of metal hydrides, UKAEA Rpt. AWRE No. 0-22/64 (June 1964). 
Pressure levels were usually $1-4 \times 10^{-5}$ torr during the evaporationcondensation of the active metal with oil-diffusion-pumped vacuum systems. Maximum vacuum achieved preceding the sorption of tritium into the target was $\sim 10^{-5}$ torr. Under these vacuum conditions, satisfactory targets were fabricated from zirconium, yttrium, and erbium metals. The thin-film coating of many sorptive metals flaked from the substrate during tritiation. Several targets flaked during irradiation with $150-k e v$ deuterons.

Target compatibility with the boundary conditions of Operation HENRE was determined by the average neutron output under 150-kev deuteron bombardment and length of target life in terms of half-life - the duration of deuteron bombardment required to reduce the neutron output by a factor of two.

From linear accelerator measurements, $\mathrm{Zr}^{3} \mathrm{H}_{\mathrm{X}}$ and $\mathrm{Y}^{3} \mathrm{H}_{2}$ as targets were eliminated due to insufficient neutron generating capability. Titanium and erbium targets were found marginally satisfactory. The neutron output and half-life of the target were found related to the thickness of the tritium-sorbed metal layer. Increasing the areal density of the film between 1 and $4 \mathrm{mg} / \mathrm{cm}^{2}$ resulted in a nearly linear increase in neutron output; output increased only slightly and then decreased with thicknesses $>4 \mathrm{mg} / \mathrm{cm}^{2}$. Since the deuteron beam reacted only with tritium atoms in the first $500 \mu \mathrm{g} / \mathrm{cm}^{2}$ of the target (before its energy was dissipated), a greater film thickness would act only as a tritium reservoir from which tritium atoms could migrate into the active area of the target face. The maximum thickness into which the tritium gas was sorbed appeared to be $\sim 4 \mathrm{mg} / \mathrm{cm}^{2}$; film thicknesses greater than this had a space where the tritium concentration was low and into which tritium atoms could migrate during irradiation away from the active face and, therefore, would lower neutron output and half-life.

Target color and neutron output also appeared qualitatively related. Targets with sufficient neutron outputs were those undergoing little or no color change during tritium sorption; the brighter and more metallic targets generated the most neutrons and had longer half-lives. These observations led to the conclusion that target characteristics depend upon preparative methods.

Since metals capable of sorbing and chemically retaining tritium are also somewhat reactive in the presence of oxygen and nitrogen, contamination of the metal film can occur by oxidation during preparation, upon exposure to the atmosphere, and during tritium sorption at high temperatures if the tritium is not purified. There are indications that contamination can be reduced by evaporation-condensation at pressures of $\sim 10^{-7}$ torr or less, by elimination or reduction of active residual gases to very low Ievels in the vacuum chamber, by using a protective coating to reduce atmospheric attack during transfer of the target from the evaporator to the tritium sorption system, and by evacuating the sorption system before tritiation to $10^{-8}$ torr or less. An ion-pumped evaporation system with electron-beam heating sources and an ion-pumped tritium sorption system are being constructed. Better quality targets which did not flake have 
been produced using a small ion-pumped system and a diffusion-pumped tritium system for the evaporation-condensation of titanium or erbium.

Two other innovations have been added: etching the 20-mil copper target backings by argon ion bombardment preceding evaporation, and overcoating the entire surface of the target with $\sim 200 \mu \mathrm{g} / \mathrm{cm}^{2}$ of cadmium following film formation. Etching with argon removed the oxide film formed by residual gas and the clean surface then produced a tenacious bond between the substrate and the condensed metal film. The cadmium overcoat protects the sorptive metal surface from atmospheric attack and can be removed by re-evaporation preceding tritium sorption. Initial results from targets prepared with titanium and erbium metals condensed onto copper substrates incorporating these improvements have been encouraging, but limitations of the vacuum level in the tritium system still resulted in surface oxidation which was detected by radiographs of tritiated targets containing spots of very low tritium concentration.

Final design and construction have begun on the evaporation and tritiation systems to be used for the Operation HENRE targets. The requisite target will be 21.5 in. in dia with an inner circular section of $14 \mathrm{in}$. dia which will be vacuum coated with either titanium or erbium. This large target area is necessary to ensure sufficient cooling to limit tritium degassing from the face (target surface temperature, $\sim 200^{\circ} \mathrm{C}$ ) under bombardment. Approximately 75 kilowatts of deuteron beam current will be expended into the target surface to generate $10^{13}$ neutrons/sec. The vacuum chamber of the evaporator is $32 \mathrm{in}$. in dia and $32 \mathrm{in}$. high. Combined titanium sublimation and a 500-liter/sec ion pump will be used a total capacity of $\sim 12,000$ liters/sec. The sorptive metal film will be condensed onto the face of the target substrate over a $180^{\circ}$ sector while the substrate rotates at $100 \mathrm{rpm}$ to achieve $>93 \%$ uniformity of areal density over the surface. An estimated $75 \mathrm{~g}$ of metal will be evaporated to form a $4-\mathrm{mg} / \mathrm{cm}^{2}$ layer. Before and during evaporation-condensation, the 39-Ib copper substrate will be heated to $\sim 350^{\circ} \mathrm{C}$ to ensure complete degasing and strong adherence of the film during tritium sorption.

The sorption system will be ion pumped and bakeable to $450^{\circ} \mathrm{C}$ to attain $10^{-8}$ to $10^{-9}$ torr vacuum levels. A smaller prototype version of this system is nearly complete and will be used to prepare 1.25-in.-dia targets for evaluation purposes. Figures 15 through 19 are photographs of the various systems. 


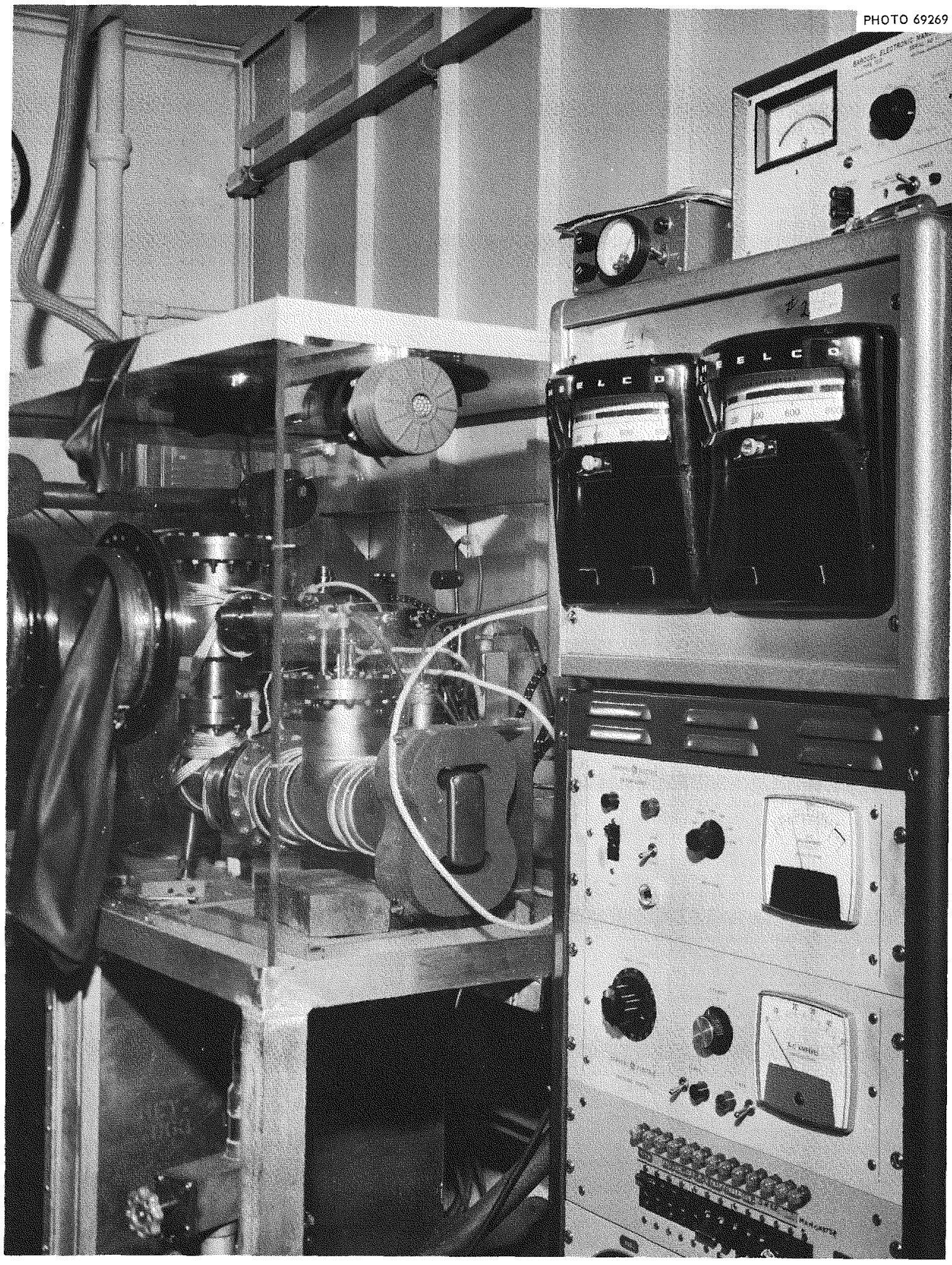

Fig. 15. Prototype Tritium-Sorption System for 1.25-in.-dia Targets. Combined titanium-sublimation, ion-pumping unit is in center of photograph. 


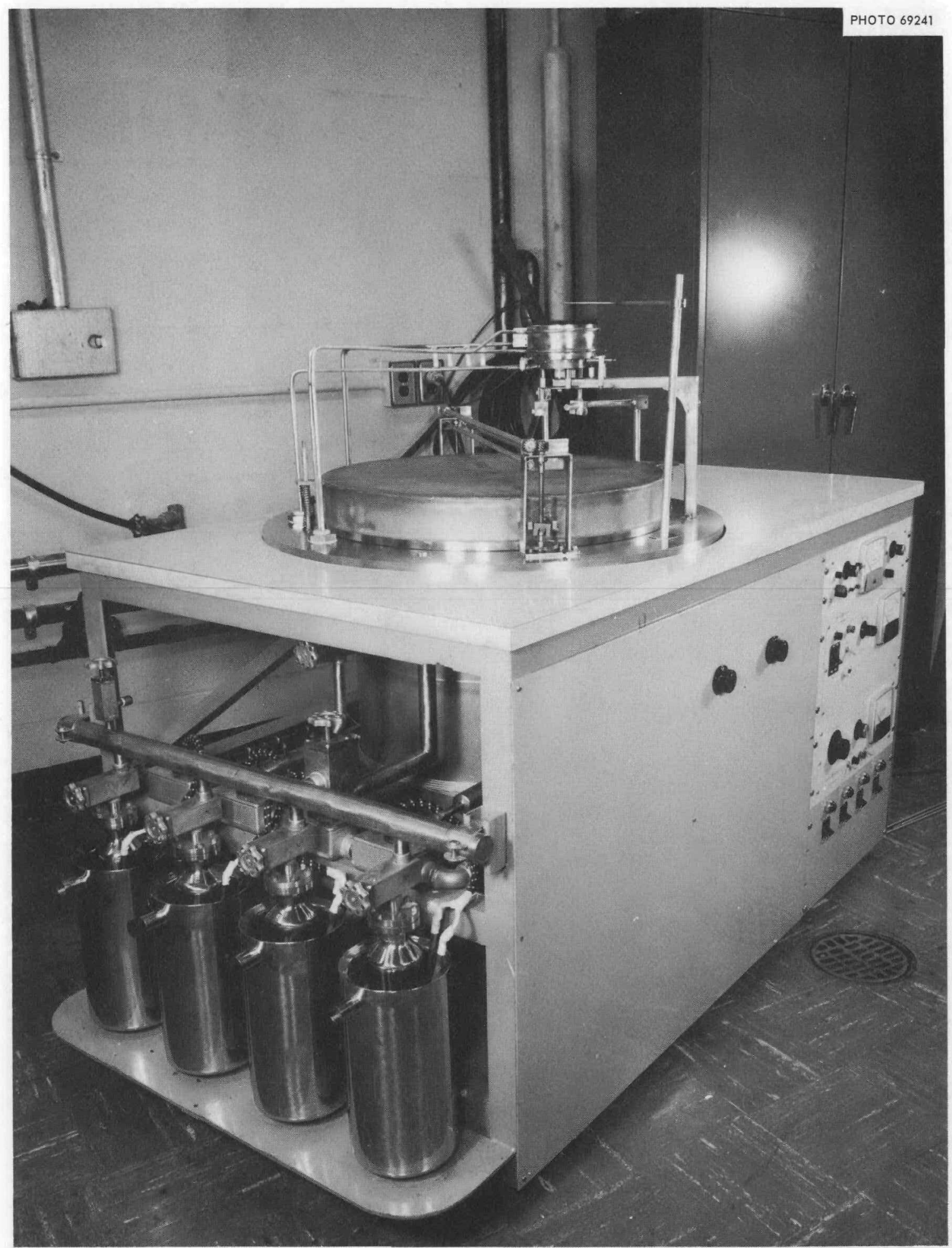

Fig. 16. Pumping System and Base Plate of Electron-Bombardment Heat Source for Erbium or Titanium Evaporation. Molecular sieve pumping is used to rough-pump the system (sieve traps in foreground). 


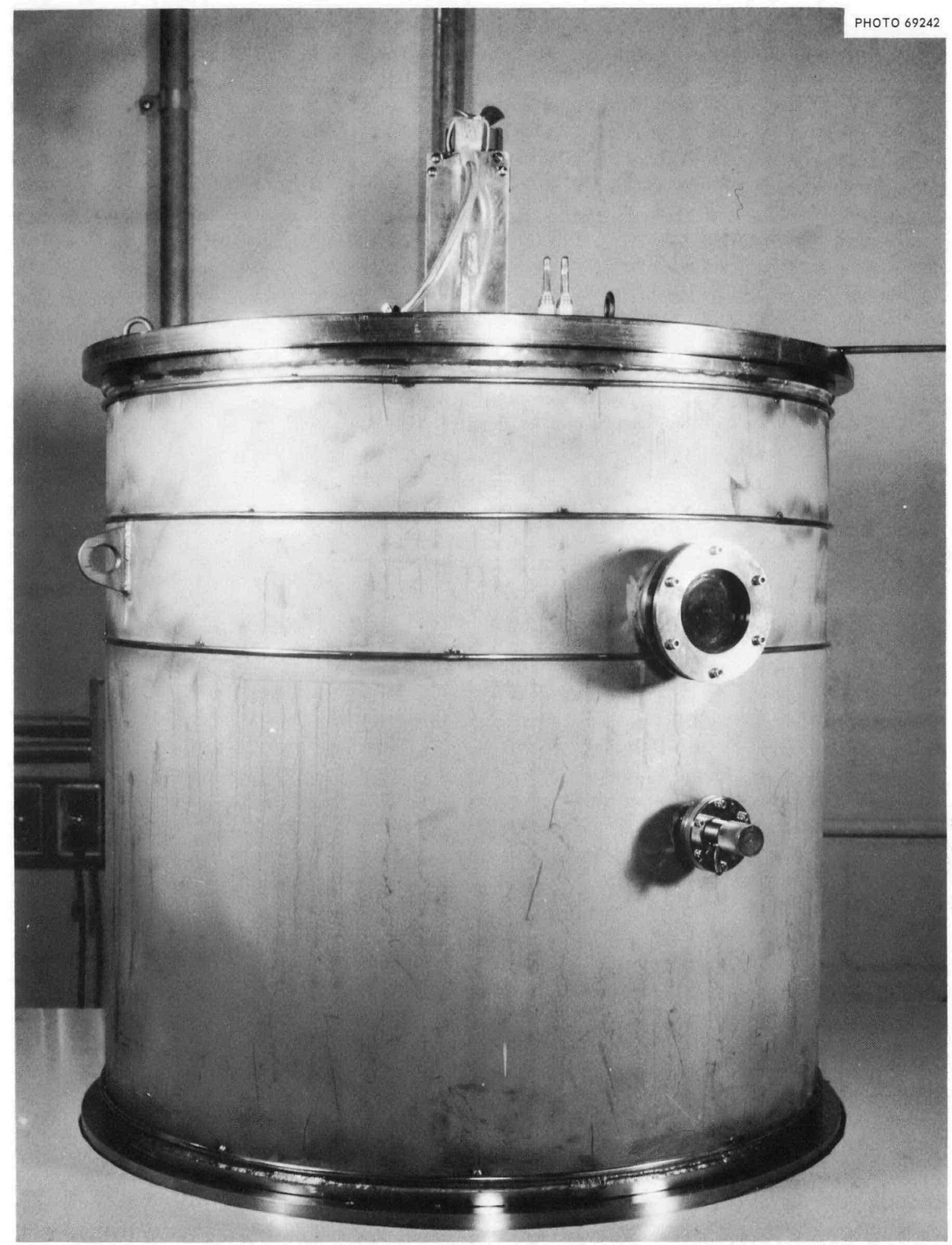

Fig. 17. Stainless Steel Evaporator Bell Jar (32 in. high by 32 in. dia). 


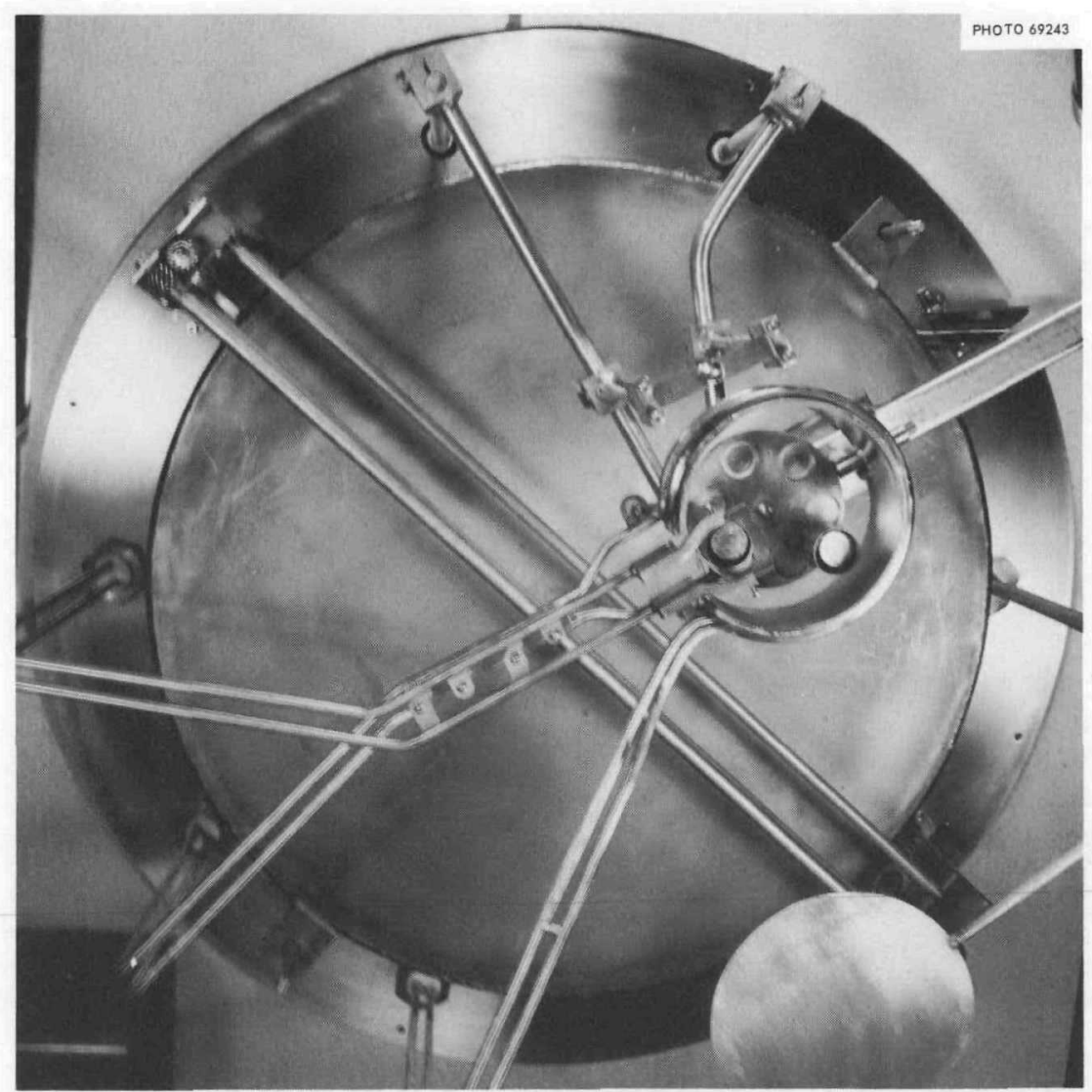

Fig. 18. Electron-Bombardment Multiple Evaporation Heat Source. Bars of erbium metal are shown in two tantalum metal crucibles.

PHOTO 69245

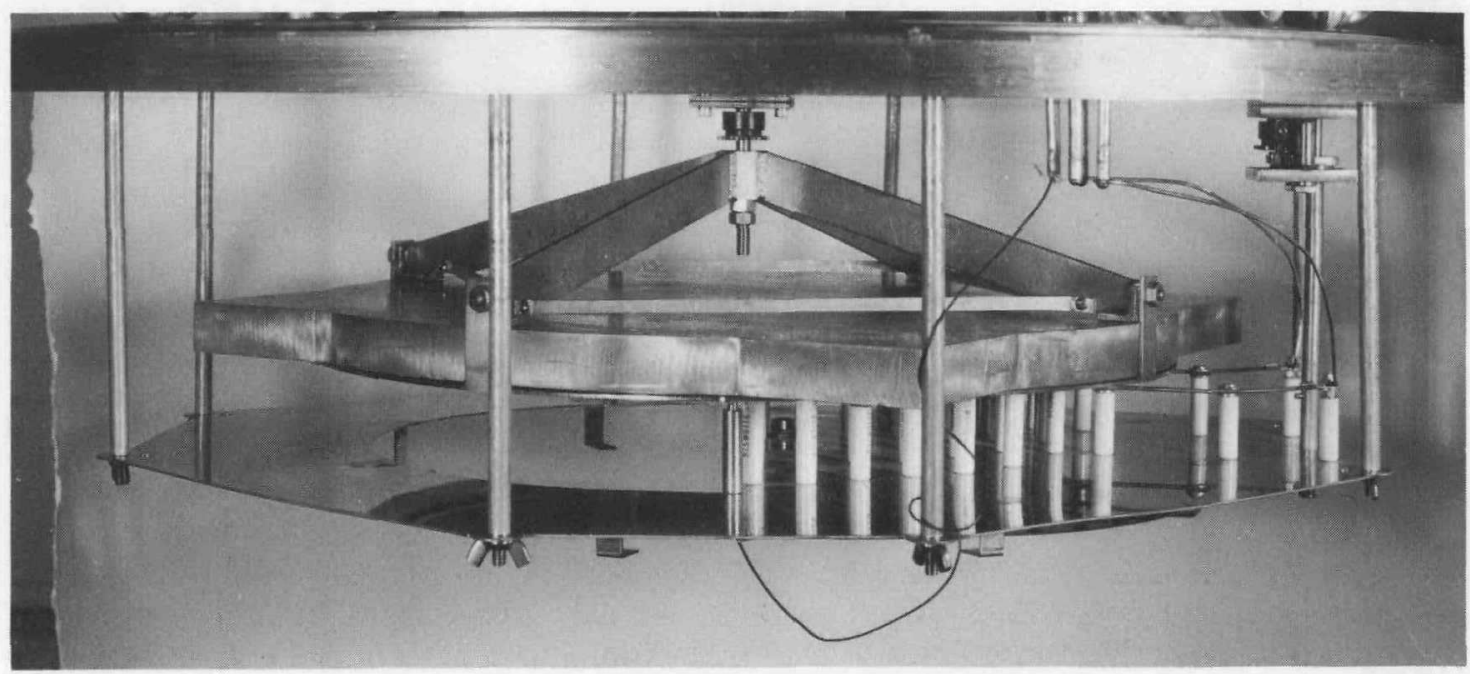

Fig. 19. Side View of Target Mounted in Rotation Carriage and the Heated Vapor Shield. Target temperature during deposition is $350^{\circ} \mathrm{C}$. 
Targets Prepared From Fissionable Isotopes

Plutonium-239 Fission Chambers

A special assembly was designed to deposit ${ }^{23}{ }^{3} \mathrm{PuO}_{2}$ on the internal and external surfaces of concentric cylinders to be used in a fission chamber. Electron bombardment heating was used since the evaporation temperature of $\mathrm{PuO}_{2}$ was estimated to be $2400-2600^{\circ} \mathrm{C}$. Each cylinder in the system could be axially rotated. with the evaporation crucible coincident with the axis of rotation of the cylinder. A second evaporation source was required to independently evaporate material onto the outer surface of each cylinder. Figure 20 illustrates the fission chamber, the nest of concentric cylinders, the boat-like tungsten crucible, and the electronemission filament used to heat the crucible.

Coating thicknesses of $100 \mu \mathrm{g} / \mathrm{cm}^{2}$ on the cylindrical surface of one fission chamber and $1000 \mu \mathrm{g} / \mathrm{cm}^{2}$ on the other with a uniformity of $\pm 10 \%$ were required. The uniformity requirement determined the design of the crucible - a 2-in.-long slotted tungsten rod, 3/16 in. in dia. The desired uniformity was obtained by uniform distribution of finely divided $\mathrm{PuO}_{2}$ in the crucible slot and rotation of the concentric cylinder at $100 \mathrm{rpm}$. Evaporation onto the outside surface of one cylinder is shown in Fig. 2l; at the left end of the cylinder the water-cooled electrical connections and support for the annular evaporation crucible and electron-emission filament can be seen. Four separate evaporations were required to achieve the appropriate thickness of $100 \mathrm{\mu g} / \mathrm{cm}^{2}$; ten or more evaporations were required for $1000 \mu \mathrm{g} / \mathrm{cm}^{2}$, using a slightly larger crucible.

The vacuum chamber in Fig. 21 consisted of a 6-in.-dia Pyrex glass pipe which was attached directly to a high-vacuum valve and a 4-in. oil diffusion pump. Ultimate vacuum levels of $\sim 3 \times 10^{-7}$ torr could be achieved, but during evaporation the pressure rose to $\sim 4 \times 10^{-5}$ torr because of the heavy gas load generated by the oxide. The entire vacuum assembly was housed. within a glove box designed to prevent plutonium contamination.

Although other compounds of plutonium with lower evaporation temperatures could have been substituted, $\mathrm{PuO}_{2}$ exhibits several unique characteristics desirable for this particular application. The oxide forms a highly polymerized coating, $\left(\mathrm{PuO}_{\mathrm{X}}\right)_{\mathrm{y}}$, which resists abrasion. The film reacts slowly with atmospheric gases, particularly water vapor, and, therefore, can be weighed with reasonable accuracy. If titanium is used as the metal substrate, very great film tenacity can be achieved between the deposit and the substrate with no special preparation of the backing other than simple degassing in vacuum.

In a manner similar to that used for preparation of these fission chamber cylinders, ${ }^{3}{ }^{3} \mathrm{Pu},{ }^{240} \mathrm{Pu},{ }^{24 I} \mathrm{Pu}$, and ${ }^{242} \mathrm{Pu}$ oxides between 50 and $3000 \mu \mathrm{g} / \mathrm{cm}^{2}$ were deposited on a variety of metal substrates and on thin carbon foils $\left(35 \mathrm{\mu g} / \mathrm{cm}^{2}\right)$ using electron bombardment evaporation techniques. Most of these deposits were used either in fission chambers or as foils to study fission fragments. Others were used as fission standards after calibration by the U. S. Bureau of Standards. 


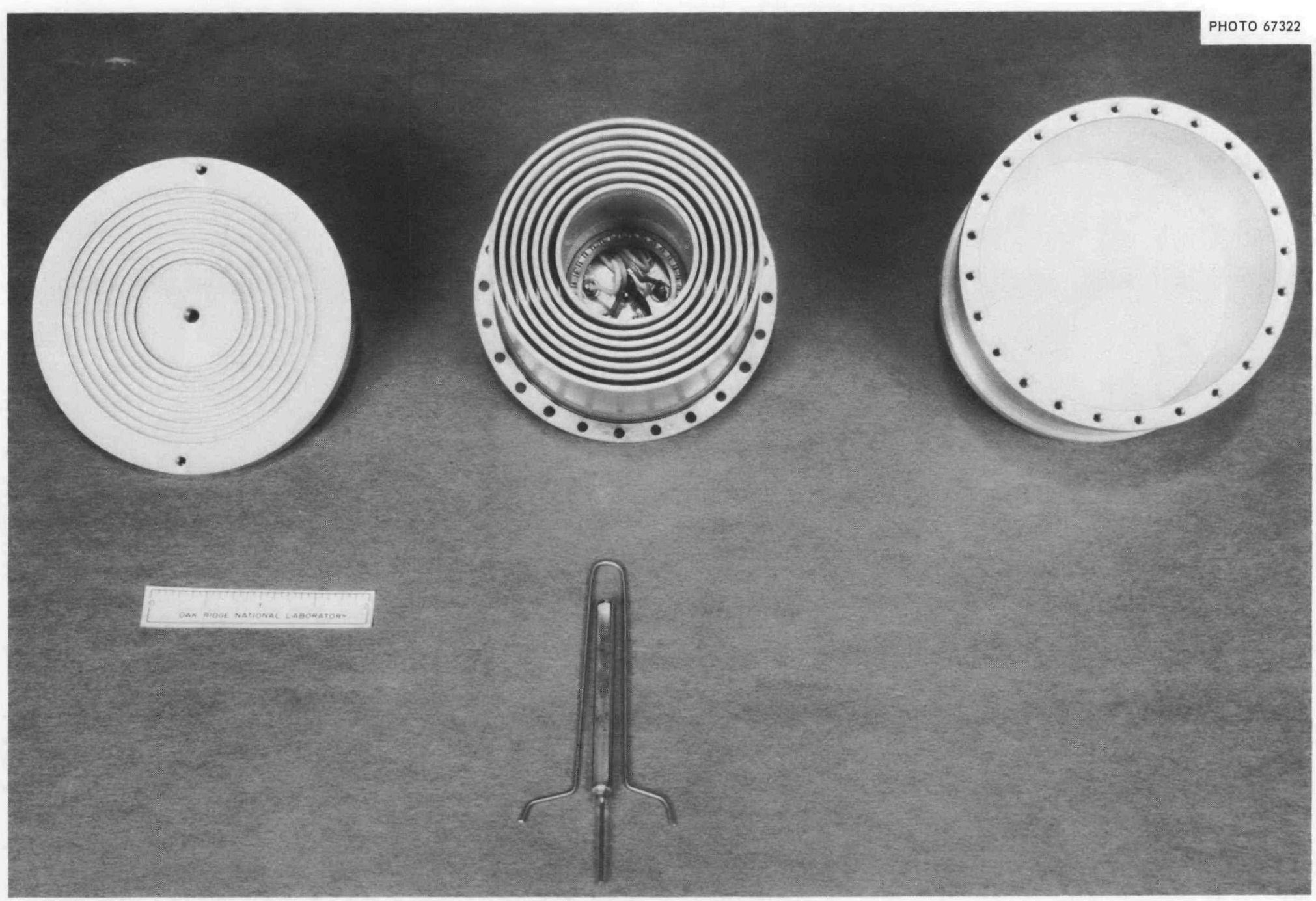

Fig. 20. Boat-like Tungsten Crucible and Electron-Emission Filament (in foreground) Used to Coat Fission Chamber Cylinders with ${ }^{23}{ }^{2} \mathrm{PuO}_{2}$. Fission chamber assembly is shown in the upper portion of the photograph. 


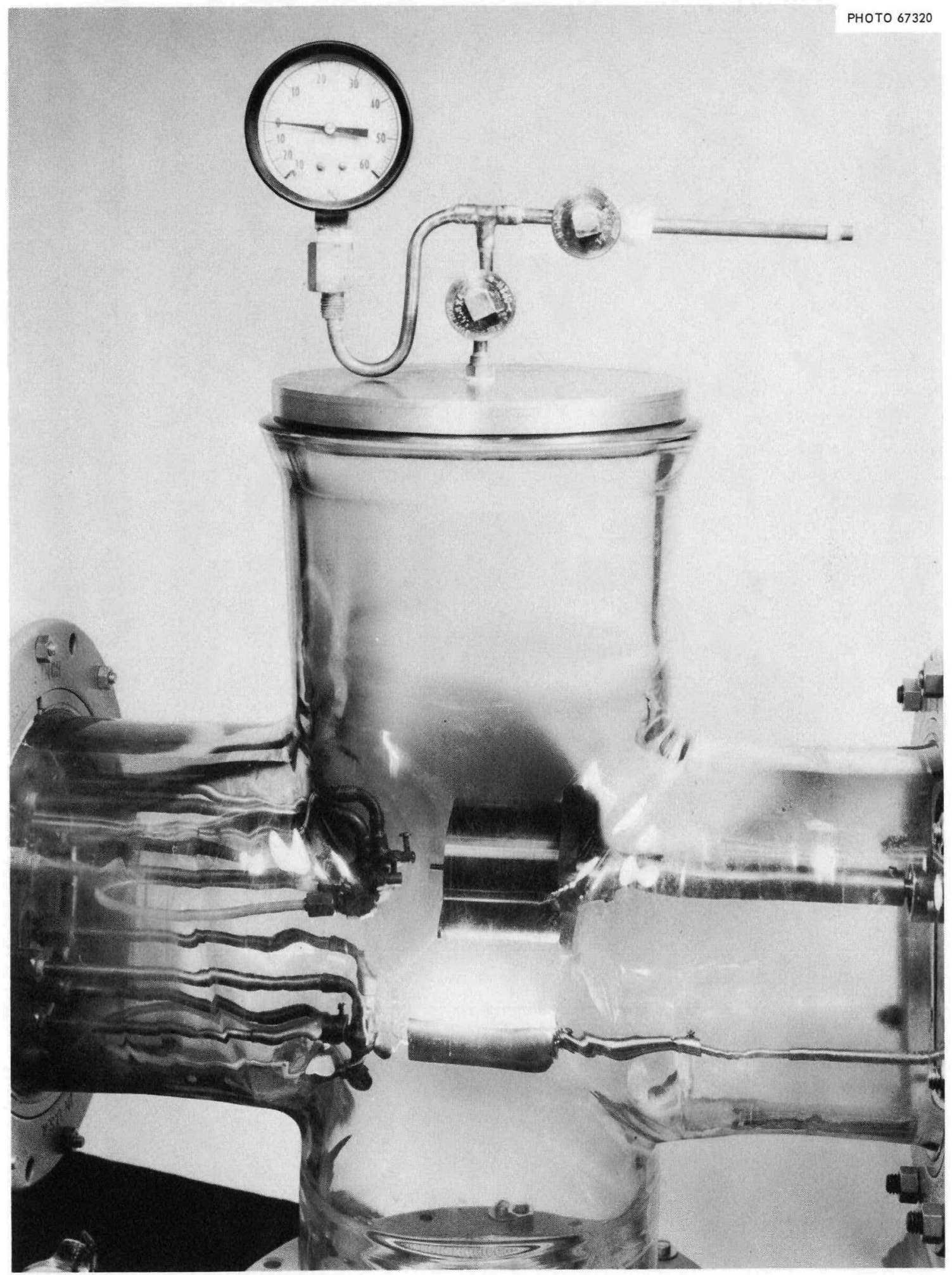

Fig. 21. Evaporation of ${ }^{239} \mathrm{PuO}_{2}$ onto Fission Chamber Cylinder in a Pyrex Glass Cross Evaporator. Cylinder was rotated at $100 \mathrm{rpm}$ above the vapor source. 
Targets for Cross-Section Measurements

Increasing numbers of inquiries have been received concerning the feasibility of preparing high-precision targets with an atom content known within $\pm 0.05 \%$ and a homogeneous atom density of $\pm 1.0 \%$ to be used as standards in cross-section measurements. The following facts were obtained from a study of ${ }^{235} \mathrm{U},{ }^{239} \mathrm{Pu}$, and ${ }^{237} \mathrm{~Np}$ : the atom content of condensed films is known within $\pm 10 \%$; uniformity of condensed films is $\pm 5 \%$; the chemical state in which atoms are deposited is generally unknown; and knowledge in analytical chemistry, radiochemistry, and nuclear physics is sufficient to fabricate standards meeting the proposed specifications.

Distilled Fissionable Metal Targets

An experimental study has begun on the direct reduction of heavy element oxides and subsequent distillation-condensation of the metals. Only small quantities of separated fissionable isotopes are available, either by calutron separation or as reactor products, and the usual chemical reduction techniques are impractical and expensive using such limited quantities. The metal products obtained by calcium reduction of the metal fluorides the usual procedure for obtaining $U, P u$, and $\mathrm{Np}$ - tend to be insufficiently pure for target fabrication, especially for rolled foils. Impurities cause severe embrittlement and must be removed before the metal can be processed into targets.

Bright, ductile ${ }^{237} \mathrm{~Np}$ metal has been obtained by reduction of ${ }^{237} \mathrm{NpO}_{2}$, using lanthanum as the reductant, and condensation in thin film form on a suitable substrate. Ductility was demonstrated by the ability of the metal to withstand flexure. Thus far, no bulk metal has been obtained for evaluation and analysis.

Rolled Foils

Uranium, U-AI alloys, and thorium foils have been prepared on the rolling mills used for preparing stable isotope foils. Thorium metal was rolled. into 2-in.-dia foils with a thickness of $0.005 \mathrm{in.;}$ foils as thin as 0.001 in. can be prepared in an inert atmosphere. Uranium isotopes as pure metal were rolled to thicknesses between 0.010 and 0.001 in. in an argon atmosphere. Geometric size varied between 2-in.-dia circles up to $40-$ in. ${ }^{2}$ strips.

Several orders were received for U-Al alloys containing between 5 and 35 wt $\%$ aluminum. Precipitation of crystallites of the intermetallic compound UAI generally causes hardening in U-A.l alloys containing $>30$ wt $\%$ aluminum. To successfully roll such alloys, samples are normally preheated and warm-rolled. With ingots of thickness $>0.125$ in., this technique was required for alloy compositions of 35 wt $\%$ aluminum; however, cold-rolling proved sufficient when the thickness was reduced to $\leq 0.050 \mathrm{in}$. About 38 in. ${ }^{2}$ of 0.005 -in. foil was prepared in this manner in two strips of approximately equal size. A total of $150 \mathrm{in.}{ }^{2}$ of $0.010-i n$. U-5\% Al foils and $410 \mathrm{in}{ }^{2}$ of $0.010-i n .{ }^{233} \mathrm{U}-10 \% \mathrm{Al}$ foils were prepared by cold-rolling. 


\section{FABRICATED TARGET DATA}

During 1964, more than 1200 targets were fabricated and shipped to customers; this total does not include more than 500 targets fabricated for special contracts such as Operation HENRE. A conservative estimate for the number of targets and forms produced, including experimental targets prepared to develop fabrication techniques, would be 2000 . The following list categorizes targets fabricated to customer specifications:

\begin{tabular}{ll} 
Stable isotope targets & 931 \\
Radioisotope targets & 119 \\
Tritium targets & 168 \\
& \\
Total & $\underline{1218}$ \\
\hline
\end{tabular}

A Iist of targets and the forms into which they may be fabricated is given in Table 2. For rolled materials, the lower thickness limit shown in Table 2 is quoted for a foil with an area of 1 in. $^{2}$; for targets prepared by vacuum evaporation, this size varies, but is usually considered to be $\leq 0.75$ in. ${ }^{2}$. For many elements lesser thicknesses of rolled foils can be prepared and various other self-supporting films and foils can be fabricated under special conditions even though such items are not listed.

Table 2. Routinely Available Targets and Their Fabricated Forms

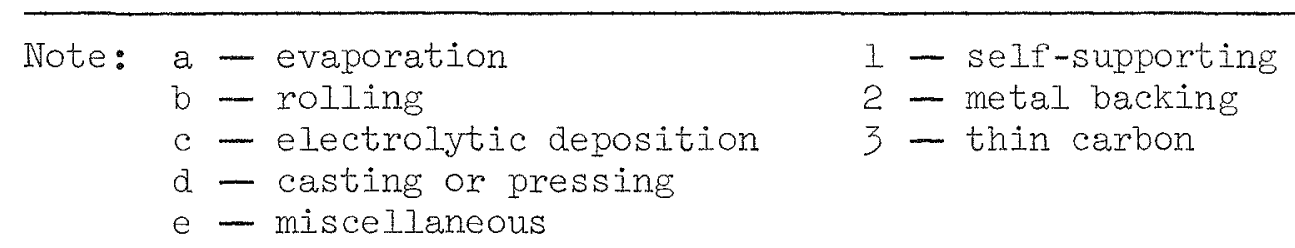

\begin{tabular}{|c|c|c|c|c|c|}
\hline Element & $\begin{array}{c}\text { Range of thickness, } \\
\mu g / \mathrm{cm}^{2}\end{array}$ & $\begin{array}{l}\text { Method of } \\
\text { preparation }\end{array}$ & Backing & & $\begin{array}{l}\text { Form of } \\
\text { deposit }\end{array}$ \\
\hline Aluminum & $\begin{array}{l}5 \text { to } 12,000 \\
150 \text { up }\end{array}$ & $\begin{array}{l}a \\
a \\
d\end{array}$ & $\begin{array}{l}2 \\
1 \\
1\end{array}$ & & $\begin{array}{l}\text { AI } \\
\text { AI } \\
\text { AI }\end{array}$ \\
\hline Americium & Undetermined & $\mathrm{a}$ & & Am & or oxide \\
\hline Antimony & 500 to 3000 & a & 1 & & $\mathrm{Sb}$ \\
\hline Arsenic & 10 to 200 & a & 2 & & As \\
\hline Barium & 10 to 1000 & $\begin{array}{l}a \\
d\end{array}$ & $\begin{array}{l}2 \\
1\end{array}$ & & $\begin{array}{l}\text { Salt } \\
\text { Salt }\end{array}$ \\
\hline Beryllium & Undetermined & a & 1,2, & 3 & $\mathrm{Be}$ \\
\hline Bismuth & 10 to undetermined & a & 2 & & $\mathrm{Bi}$ \\
\hline Boron & $\begin{array}{l}20 \text { to } 250 \\
10 \text { to } 1000\end{array}$ & $\begin{array}{l}\mathrm{a} \\
\mathrm{a}\end{array}$ & $\frac{1}{2}$ & & $\begin{array}{l}B \\
B\end{array}$ \\
\hline Bromine & 10 to 1000 & $\begin{array}{l}a \\
d\end{array}$ & $\begin{array}{l}2 \\
1\end{array}$ & & $\begin{array}{l}\text { Bromide } \\
\text { Bromide }\end{array}$ \\
\hline
\end{tabular}


Table 2. continued

\begin{tabular}{|c|c|c|c|c|}
\hline Element & $\begin{array}{c}\text { Range of thickness, } \\
\mu \mathrm{g} / \mathrm{cm}^{2}\end{array}$ & $\begin{array}{l}\text { Method of } \\
\text { preparation }\end{array}$ & Backing & $\begin{array}{l}\text { Form of } \\
\text { deposit }\end{array}$ \\
\hline Cadmium & $\begin{array}{l}10 \text { to } 200 \\
1000 \text { up }\end{array}$ & $\begin{array}{l}a \\
b \\
d\end{array}$ & $\begin{array}{l}2 \\
1 \\
1\end{array}$ & $\begin{array}{c}\mathrm{Cd} \\
\mathrm{Cd} \\
\text { Chloride }\end{array}$ \\
\hline Calcium & $\begin{array}{l}10 \text { to } 1000 \\
1000 \text { up }\end{array}$ & $\begin{array}{l}a \\
b \\
d\end{array}$ & $\begin{array}{l}2 \\
1 \\
1\end{array}$ & $\begin{array}{l}\mathrm{Ca} \\
\mathrm{Ca} \\
\mathrm{Ca}\end{array}$ \\
\hline $\begin{array}{l}\text { Carbon } \\
\text { NormaI } \\
\text { Isotopic }\end{array}$ & $\begin{array}{l}10 \text { to } 200 \\
10 \text { to } 200\end{array}$ & $\begin{array}{l}a \\
\mathrm{e}\end{array}$ & $\begin{array}{l}1 \\
2\end{array}$ & $\begin{array}{l}\mathrm{C} \\
\mathrm{C}\end{array}$ \\
\hline Cerium & 10 to undetermined. & a & 2 & Oxide \\
\hline Cesium & 10 to 1000 & a & 2 & Salt \\
\hline Chlorine & 10 to 1000 & $\begin{array}{l}a \\
d\end{array}$ & $\begin{array}{l}2 \\
1\end{array}$ & $\begin{array}{l}\text { Salt } \\
\text { Salt }\end{array}$ \\
\hline Chromium & $\begin{array}{l}500 \text { to } 3000 \\
10 \text { to undetermined }\end{array}$ & $\begin{array}{l}a \\
a \\
d\end{array}$ & $\begin{array}{l}1 \\
2 \\
1\end{array}$ & $\begin{array}{l}\mathrm{Cr} \\
\mathrm{Cr} \\
\mathrm{Cr}\end{array}$ \\
\hline CobaIt & $\begin{array}{l}1000 \text { up } \\
10 \text { up }\end{array}$ & $\begin{array}{l}b \\
a\end{array}$ & $\frac{1}{2}$ & $\begin{array}{l}\text { Co } \\
\text { Co }\end{array}$ \\
\hline Copper & $\begin{array}{l}1000 \text { up } \\
10 \text { to } 1000 \\
200 \mathrm{up}\end{array}$ & $\begin{array}{l}b \\
c \\
a \\
d\end{array}$ & $\begin{array}{l}1 \\
2 \\
1 \\
1\end{array}$ & $\begin{array}{l}\mathrm{Cu} \\
\mathrm{Cu} \\
\mathrm{Cu} \\
\mathrm{Cu}\end{array}$ \\
\hline Erbium & $\begin{array}{l}10 \text { to undetermined } \\
\text { Undetermined }\end{array}$ & $\begin{array}{l}a \\
b\end{array}$ & $\begin{array}{l}2 \\
1\end{array}$ & $\begin{array}{l}\operatorname{Er} \\
\operatorname{Er}\end{array}$ \\
\hline Europium & $\begin{array}{l}10 \text { to undetermined } \\
\text { Undetermined }\end{array}$ & $\begin{array}{l}a \\
b\end{array}$ & $\begin{array}{l}2 \\
1\end{array}$ & $\begin{array}{l}\mathrm{Eu} \\
\mathrm{Eu}\end{array}$ \\
\hline Fluorine & 25 to 500 & a & 2 & Fluoride \\
\hline Gallium & $\begin{array}{l}10 \text { to undetermined } \\
10 \text { to } 200\end{array}$ & $\begin{array}{l}a \\
a \\
d\end{array}$ & $\begin{array}{l}2 \\
3 \\
1\end{array}$ & $\begin{array}{c}\mathrm{Ga} \\
\mathrm{Ga}_{2} \mathrm{O}_{3} \\
\mathrm{Ga}_{2} \mathrm{O}_{3}\end{array}$ \\
\hline Germanium & $\begin{array}{l}10 \text { up } \\
\text { Undetermined }\end{array}$ & $\begin{array}{l}a \\
a\end{array}$ & $\begin{array}{l}2 \\
1\end{array}$ & $\begin{array}{l}\text { Ge } \\
\text { Ge }\end{array}$ \\
\hline Gold & $\begin{array}{l}10 \text { up } \\
\text { Undetermined }\end{array}$ & $\begin{array}{l}a \\
b \\
d\end{array}$ & $\begin{array}{l}2 \\
1 \\
1\end{array}$ & $\begin{array}{l}\mathrm{Au} \\
\mathrm{Au} \\
\mathrm{Au}\end{array}$ \\
\hline Indium & $\begin{array}{l}5000 \text { up } \\
10 \mathrm{up}\end{array}$ & $\begin{array}{l}b \\
a \\
d\end{array}$ & $\begin{array}{l}1 \\
2 \\
1\end{array}$ & $\begin{array}{l}\text { In } \\
\text { In } \\
\text { In }\end{array}$ \\
\hline Iridium & 10 to 100 & $\mathrm{a}$ & 2 & $\operatorname{Ir}$ \\
\hline Iron & $\begin{array}{l}1000 \text { up } \\
10 \text { up }\end{array}$ & $\begin{array}{l}\mathrm{b} \\
\mathrm{a} \\
\mathrm{d}\end{array}$ & $\begin{array}{l}1 \\
2 \\
1\end{array}$ & $\begin{array}{l}\mathrm{Fe} \\
\mathrm{Fe} \\
\mathrm{Fe}\end{array}$ \\
\hline
\end{tabular}


Table 2. continued

\begin{tabular}{|c|c|c|c|c|}
\hline Element & $\begin{array}{c}\text { Range of thickness, } \\
\mu \mathrm{g} / \mathrm{cm}^{2}\end{array}$ & $\begin{array}{l}\text { Method of } \\
\text { preparation }\end{array}$ & Backing & $\begin{array}{l}\text { Form of } \\
\text { deposit }\end{array}$ \\
\hline Lanthanum & Io to undetermined & $\begin{array}{l}a \\
d\end{array}$ & $\begin{array}{l}2 \\
1\end{array}$ & $\begin{array}{l}\text { La } \\
\text { La }\end{array}$ \\
\hline Iead. & $\begin{array}{l}8000 \text { up } \\
1000 \text { to } 8000 \\
10 \text { to } 1000\end{array}$ & $\begin{array}{l}\mathrm{b} \\
\mathrm{a} \\
\mathrm{a} \\
\mathrm{d}\end{array}$ & $\begin{array}{l}1 \\
1 \\
2 \\
1\end{array}$ & $\begin{array}{l}\mathrm{Pb} \\
\mathrm{Pb} \\
\mathrm{Pb} \\
\mathrm{Pb}\end{array}$ \\
\hline Lithium & $\begin{array}{l}4000 \text { to any cast size } \\
10 \text { to } 500 \\
10 \text { to } 500\end{array}$ & $\begin{array}{l}b, a \\
a \\
a\end{array}$ & $\begin{array}{l}1 \\
3 \\
2\end{array}$ & $\begin{array}{l}\mathrm{Li} \\
\mathrm{LiH} \\
\mathrm{Li}\end{array}$ \\
\hline Iutetium & Io to undetermined & a & 2 & Iu \\
\hline Magnesium & 1000 to 8000 & $\begin{array}{l}\mathrm{a} \\
\mathrm{a}\end{array}$ & $\begin{array}{l}1 \\
1\end{array}$ & $\begin{array}{l}\mathrm{Mg} \\
\mathrm{Mg}\end{array}$ \\
\hline Manganese & 10 to undetermined & a & 2 & $\operatorname{Mn}$ \\
\hline Mercury & $\begin{array}{l}1000 \text { to } 4000 \\
\text { Undetermined }\end{array}$ & $\begin{array}{l}c \\
a\end{array}$ & ${ }_{2}^{\text {on } A u}$ & $\begin{array}{l}\mathrm{Hg} \\
\text { Salt }\end{array}$ \\
\hline Molybdenum & $\begin{array}{l}10 \text { to } 1000 \\
1000 \text { up }\end{array}$ & $\begin{array}{l}\mathrm{a} \\
\mathrm{b}\end{array}$ & $\begin{array}{l}2 \\
1\end{array}$ & $\begin{array}{l}\text { Mo } \\
\text { Mo }\end{array}$ \\
\hline Neodymium & Io to undetermined & a & 2 & Nd. \\
\hline Nickel & $\begin{array}{l}1000 \mathrm{up} \\
10 \mathrm{up}\end{array}$ & $\begin{array}{l}b \\
a \\
d\end{array}$ & $\begin{array}{l}1 \\
2 \\
1\end{array}$ & $\begin{array}{l}\mathrm{Ni} \\
\mathrm{Ni} \\
\mathrm{Ni}\end{array}$ \\
\hline Niobium & $\begin{array}{l}10 \text { up } \\
1000 \text { up }\end{array}$ & $\begin{array}{l}\mathrm{a} \\
\mathrm{b}\end{array}$ & $\begin{array}{l}2 \\
1\end{array}$ & $\begin{array}{l}\mathrm{Nb} \\
\mathrm{Nb}\end{array}$ \\
\hline Palladium & $\begin{array}{l}1000 \text { up } \\
10 \text { up }\end{array}$ & $\begin{array}{l}\mathrm{b} \\
\mathrm{a} \\
\mathrm{d}\end{array}$ & $\begin{array}{l}1 \\
2 \\
1\end{array}$ & $\begin{array}{l}\mathrm{Pd} \\
\mathrm{Pd} \\
\mathrm{Pd}\end{array}$ \\
\hline Platinum & $\begin{array}{l}4000 \text { up } \\
10 \text { up }\end{array}$ & $\begin{array}{l}b \\
a \\
a\end{array}$ & $\begin{array}{l}1 \\
2 \\
1\end{array}$ & $\begin{array}{l}\text { Pt } \\
\text { Pt } \\
\text { Pt }\end{array}$ \\
\hline Plutonium & $10 \mathrm{up}$ & a & 2 & Oxide \\
\hline Potassium & 7500 to any cast size & $b, d$ & 1 & $\mathrm{~K}$ \\
\hline Promethium & $10 \mathrm{up}$ & a & 2 & Oxide \\
\hline Radium & $10 \mathrm{up}$ & $\mathrm{a}$ & 2 & Bromide \\
\hline Samarium & $\begin{array}{l}1000 \text { to undetermined } \\
\text { 10 up }\end{array}$ & $\begin{array}{l}\mathrm{b} \\
\mathrm{a}\end{array}$ & $\frac{1}{2}$ & $\begin{array}{l}\mathrm{Sm} \\
\mathrm{Sm}\end{array}$ \\
\hline Scandium & $\begin{array}{l}10 \text { up } \\
1000 \text { up }\end{array}$ & $\begin{array}{l}a \\
b\end{array}$ & $\begin{array}{l}2 \\
1\end{array}$ & $\begin{array}{l}\mathrm{Sc} \\
\mathrm{Se}\end{array}$ \\
\hline
\end{tabular}


Table 2. continued

\begin{tabular}{|c|c|c|c|c|}
\hline Element & $\begin{array}{l}\text { Range of thickness, } \\
\mu \mathrm{g} / \mathrm{cm}^{2}\end{array}$ & $\begin{array}{l}\text { Method of } \\
\text { preparation }\end{array}$ & Backing & $\begin{array}{l}\text { Form of } \\
\text { deposit } \\
\end{array}$ \\
\hline Selenium & $\begin{array}{l}300 \text { to } 5000 \\
10 \text { to } 5000\end{array}$ & $\begin{array}{l}a \\
a \\
d\end{array}$ & $\begin{array}{l}1 \\
2 \\
1\end{array}$ & $\begin{array}{l}\mathrm{Se} \\
\mathrm{Se} \\
\mathrm{Se}\end{array}$ \\
\hline Silver & $\begin{array}{l}1000 \text { up } \\
100 \text { to } 5000 \\
10 \text { to } 1000\end{array}$ & $\begin{array}{l}\mathrm{b} \\
\mathrm{a} \\
\mathrm{a} \\
\mathrm{d}\end{array}$ & $\begin{array}{l}1 \\
1 \\
2 \\
1\end{array}$ & $\begin{array}{l}\mathrm{Ag} \\
\mathrm{Ag} \\
\mathrm{Ag} \\
\mathrm{Ag}\end{array}$ \\
\hline Sodium & 7500 to any cast size & $b, a$ & 1 & $\mathrm{Na}$ \\
\hline Sulfur & $\begin{array}{l}5000 \text { up } \\
10 \text { to } 100\end{array}$ & $\begin{array}{l}a \\
a\end{array}$ & $\frac{1}{2}$ & $\begin{array}{l}S \\
S\end{array}$ \\
\hline Tantalum & $\begin{array}{l}2000 \text { up } \\
10 \text { to } 1000\end{array}$ & $\begin{array}{l}\mathrm{b} \\
\mathrm{a}\end{array}$ & $\frac{1}{2}$ & $\begin{array}{l}\mathrm{Ta} \\
\mathrm{Ta}\end{array}$ \\
\hline Technetium & 10 to 1000 & a & 2 & Te \\
\hline Tellurium & 10 to 1000 & $\begin{array}{l}a \\
a\end{array}$ & 2,3 & $\begin{array}{l}\text { Te } \\
\text { Te }\end{array}$ \\
\hline Thallium & $\begin{array}{l}8000 \text { up } \\
10 \text { up }\end{array}$ & $\begin{array}{l}\mathrm{b} \\
\mathrm{a}\end{array}$ & $\frac{1}{2}$ & $\begin{array}{l}\mathrm{TI} \\
\mathrm{TI}\end{array}$ \\
\hline 'Tin & $\begin{array}{l}4000 \text { up } \\
10 \text { to } 1000 \\
500 \text { to } 4000\end{array}$ & $\begin{array}{l}b \\
a \\
a\end{array}$ & $\begin{array}{l}1 \\
2 \\
1\end{array}$ & $\begin{array}{l}\mathrm{Sn} \\
\mathrm{Sn} \\
\mathrm{Sn}\end{array}$ \\
\hline Titanium & $\begin{array}{l}1000 \text { up } \\
10 \text { up }\end{array}$ & $\begin{array}{l}\mathrm{b} \\
\mathrm{a}\end{array}$ & $\frac{1}{2}$ & $\begin{array}{l}\text { Ti } \\
\text { Ti }\end{array}$ \\
\hline Tritium* & 100 to 5000 & e & 2 & \\
\hline Tungsten & $\begin{array}{l}\text { In Cu matrix } \\
2000 \text { up }\end{array}$ & $\begin{array}{l}\mathrm{b} \\
\mathrm{d}\end{array}$ & $\begin{array}{l}2 \\
1\end{array}$ & $\begin{array}{l}\text { W } \\
W\end{array}$ \\
\hline Uranium & $\begin{array}{l}10 \text { up } \\
1 \text { mil up }\end{array}$ & $\begin{array}{l}\mathrm{a} \\
\mathrm{b}\end{array}$ & $\begin{array}{l}2 \\
1\end{array}$ & $\begin{array}{l}\text { Oxide } \\
\text { U }\end{array}$ \\
\hline Vanadium & $\begin{array}{l}1000 \text { up } \\
10 \text { up }\end{array}$ & $\begin{array}{l}\mathrm{b} \\
\mathrm{a}\end{array}$ & $\begin{array}{l}1 \\
2\end{array}$ & $\begin{array}{l}V \\
V\end{array}$ \\
\hline Ytterbium & $\begin{array}{l}10 \text { to undetermined } \\
1000 \text { up }\end{array}$ & $\begin{array}{l}\mathrm{a} \\
\mathrm{b}\end{array}$ & $\begin{array}{l}2 \\
1\end{array}$ & $\begin{array}{l}\mathrm{Yb} \\
\mathrm{Yb}\end{array}$ \\
\hline Yttrium & $\begin{array}{l}10 \text { to undetermined } \\
2000 \text { up }\end{array}$ & $\begin{array}{l}\mathrm{a} \\
\mathrm{b}\end{array}$ & $\begin{array}{l}2 \\
1\end{array}$ & $\begin{array}{l}Y \\
Y\end{array}$ \\
\hline Zinc & $\begin{array}{l}1000 \text { up } \\
10 \text { up }\end{array}$ & $\begin{array}{l}\mathrm{b} \\
\mathrm{a}\end{array}$ & $\frac{1}{2}$ & $\begin{array}{l}\mathrm{Zn} \\
\mathrm{Zn}\end{array}$ \\
\hline Zirconium & $\begin{array}{l}1000 \text { up } \\
10 \text { to } 5000\end{array}$ & $\begin{array}{l}b \\
b\end{array}$ & $\frac{1}{2}$ & $\begin{array}{l}\mathrm{Zr} \\
\mathrm{Zr}\end{array}$ \\
\hline
\end{tabular}

*Adsorbed on Zr, Y, Ti, or Er 
1. E. H. Kobisk, Target development, April-September 1963, USAEC Rpt. ORNL-TM-718, Oak Ridge National Laboratory (1964).

2. H. I. Adair and E. H. Kobisk, Boron film preparation using an electron beam evaporator, Ninth National Vacuum Symposium, American Vacuum Society (1962).

3. W. D. Box, Vacuum distillation of magnesium metal, USAEC Rpt. ORNLTM-749, Oak Ridge National Laboratory (Aug. 1964).

4. H. C. Kelly, T. J. Flynn, C.W. Davis, and Sidney Johnson, The preparation of transistor grade silicon from silane or analogous compounds, Metal Hydrides, Inc., Research and Development Laboratories, Beverly, Mass.

5. C. H. Lewis, M. B. Givsto, and Sidney Johnson, The preparation of transistor grade silicon from silane or analogous compounds, Metal Hydrides, Inc., Beverly, Mass. 
page blank 


$$
\begin{gathered}
\text { ORNL-3829 } \\
\text { UC-23 - Isotopes-Industrial Technology } \\
\text { TID-4500 (43rd ed.) }
\end{gathered}
$$

INTERNAT, DISTRIBUTION

1. Biology Library

2-4. Central Research Iibrary

5. Reactor Division Library

6-7. ORNL - Y-12 Technical Library Document Reference Section

8-27. Laboratory Records Department

28. Laboratory Records, ORNI R.C.

29. P. S. Baker

30. Russell Baldock

31. E. E. Beauchamp

32. W. A. Bell

33. R. E. Biggers

34. G. E. Boyd

35. T. A. Butler

36. F. N. Case

37. J. W. Cleland

38. T. F. Connolly

39. J. A. Cox

40. F. I. Culler

41. F. F. Dyer

42. J. L. Fowler

43. J. E Frye, Jr.

44. J. H. Gillette

\author{
45. W. M. Good \\ 46. H. R. Gwinn \\ 47. R. I. Hahn \\ 48. M. T. Kelley \\ 49. C. V. Ketron \\ 50. E. H. Kobisk \\ 5I. R. H. Lafferty, Jr. \\ 52. E. Lamb \\ 53. Ingrid B. Lane \\ 54. C. E. Larson \\ 55. R. S. Livingston \\ 56. I. O. Love \\ 57. H. G. MacPherson \\ 58. R. G. Niemeyer \\ 59. W. K. Prater \\ 60. M. E. Ramsey \\ 61. R. A. Robinson \\ 62. A. F. Rupp \\ 63. H. E. Seagren \\ 64. M. J. Skinner \\ 65. K. A. Spainhour \\ 66. A. M. Weinberg \\ 67. A. Zucker
}

EXTERNAI DISTRIBUTION

68-75. P. C. Aebersold, Division of Isotopes Development, AEC, Washington, D.C.

76. H. D. Bruner, Division of Biology and Medicine, AEC, Washington, D.C.

77. D. C. Davis, Research and Development Division, AEC, ORO

78. K. A. Gschneidner, Jr., Department of Metallurgy and Institute for Atomic Research, Iowa State University, Ames, Iowa 50012

79. J. W. Irvine, 6-426, MIT, Cambridge, Massachusetts

80. T. R. Jones, Division of Research, AEC, Washington, D.C.

81. G. A. Kolstad, Division of Research, AEC, Washington, D.C.

82. R. B. Martin, Research and Development Division, AEC, ORO

83. P. W. McDaniel, Division of Research, AEC, Washington, D.C.

84. G. I. Rogosa, Division of Research, AEC, Washington, D.C.

85. H. M. Roth, Research and Development Division, AEC, ORO

86. L. G. Stang, Hot Laboratory Division, Brookhaven National Laboratory, Upton, Long Island, New York

87. J.W. Vanderryn, Office of General Manager, AEC, Washington, D.C.

88. A. R. Van Dyken, Division of Research, AEC, Washington, D.C.

89-383. Given distribution as shown in TID-4500 (43rd ed.) under Isotopes-Industrial Technology category (75 copies - CFSTI) 